






\section{THE}

\section{TRANSACIIONS}

\section{THE LINNEAN SOCIETY OF LONDO}

THE PERCY SLADEN TRUST EXPEDITIUN

TO

TIIE IN D IAN OCEAN IN 1905.

UNDER THE LEADERSHIP OF

MR. J. STANLEY GARDINER.

No. XIV.-REPORT ON THE MARINE FISHES COLLECTED BY Mr. J. STANIEY GARDINER IN THE INDIAN OCEAN.

By C. TAte Regan, M.A.


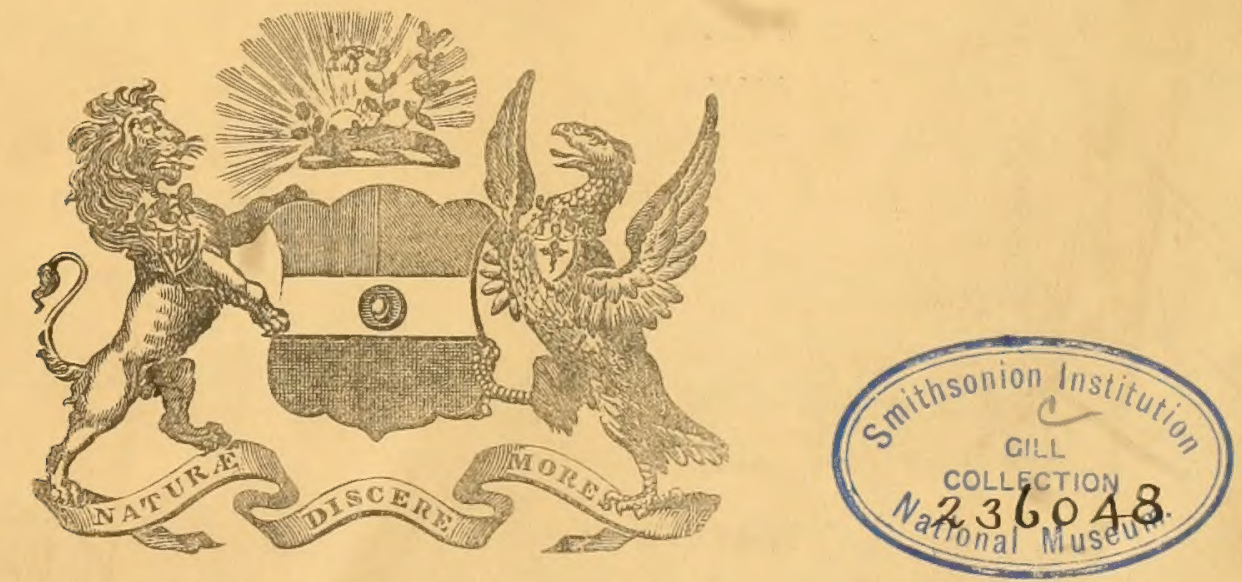

L O N 1 O $\mathrm{O}$

PRINTWI) FOR THE LINNEAN SOCIEY'T

BY TAYLOK AND FIRANCIS, RWH LION COURT, FI,EET STREET.

SOTD AT THE SOCIETY'S APARTMENTS, BURLINGTON-HOUSE, PICCADILLY, W., ANI BY LONGMANS, GREEN, AND CO, PATERNOSTER-ROW. 



\title{
No. XIV.-REPOR' ON THE MARINE FISHES COLLECTED BY Mr. J. S'TANLEY GARDINER IN THE INDIAN OCEAN.
}

\author{
By C. 'Th'te liegar, MI.A. \\ (Communicated by J. STANeer Gardiner, M.A., F.L.S.)
}

(Plates 23-32.)

Read tith June. 1907.

The marine fishes collected by Mr. Gardiner in his two expeditions comprise examples of 185 species, of which 51 are new to science and 16 more were previously unrepresented in the British Museum collection; some remarkable new generic types have also been discovered. In addition, there are a number of small "plankton" fishes, Scopelus, Gonostoma, \&c., with some Leptocephali, and also some small specimens dreciged in the lagoons of the MIaldives, which I have not been able to determine specifically.

Several of the new species are inhabitants of the deep sea and the others in great part pertain to genera (e.g. Champsodon, Callionymus, Scaops) the species of which have been considered to be more variable and more widely distributed than appears to be the case on a critical examination.

Many of the species enumerated are already knowu to have a wide distribution in the tropical Indo-Pacific; the ascertained range of several others has been considerably extended by means of the collections here dealt with. On the other hand, some species which tere originally described from Japan and which have since been recorded from Indian seas (e. g. Callionymus longicaudatus, Platycephalus spinosus, Scaops grandisquamis) are now shown not to occur in the Indian Ocean, in which they are represented by allied, but specifically distinct types.

\section{Stomiatidæ.}

\section{BOROSTOMIAS, gen. nov.}

Differs from Astronesthes, Richards, in having the teeth on the maxillary few and wide-set, instead of numerous and in a continuous series. In addition to the new species described below, this genus includes Astronesthes richarlsonir, Poey, and A. elucens, Brauer.

1. Borostomias bruueri, sp.n. (Plate 23. fig. 1.)

Depth of body $5 \frac{1}{2}$ in the length, length of head 4. Snout longer than eye, the diameter of which is 8 in the length of head and 2 in the interorbital width. Month very wide, the lower jaw scarcely shorter than the head; barbel $1 \frac{1}{3}$ the length of head. Lower series of photophores numbering 36 in advance of the ventrals, of which 12 are in SECOND SERIES.-ZOOLOGY, VOL. XII. 
advance of the pectorals; 14 or 15 photophores in the lower series from ventrals to anterior part of anal and 11 or 12 in the series from middle of anal to caudal. Upper series of photophores $36 \mathrm{or} 37$ in number, running from above the pectoral to above the middle of anal. Dorsal 13; origin above the ventrals, equidistant from occiput and base of caudal. Inal 15, its origin some distance behind the end of the dorsal. Greyish; peritoneum blackish.

Plankton, $l l, 750-0$ fathoms, near Desroches Atoll.

A single specimen, $110 \mathrm{~mm}$. in total length.

Evidently closely allied to the Astronesthes elucens of Brauer, which differs in the larger eye $\left(6 \frac{2}{5} \mathrm{in}\right.$ the length of the head in a specimen of $146 \mathrm{~mm}$.) and in having only 22 photophores in the upper series, which terminates above the ventral fins.

I have named this species after Dr. A. Brauer, in recognition of his recent work on the deep-sea fishes of the 'Valdivia' expedition.

2. Chauliodus slouni, Bl. Schn.

Plankton, N, 600-0 fathoms, north of Peros Atoll.

3. Melanostomias valdivice, Brauer.

Plankton, s, 500-750 fathoms, near Farquhar Atoll.

A specimen of $60 \mathrm{~mm}$. has only 10 teeth in the posterior maxillary series instead of 28 as in the larger specinen (16ว mm.) described by Brauer.

4. Argyropelecus affinis, Garm.

Plankton, s, 750-1000 fathoms, near Farquhar Atoll.

5. Argyropelecus sladeni, sp.n.

Depth of body $1 \frac{3}{5}$ in the length, length of head $3 \frac{2}{3}$. Two spines at the angle of the præoperculum, one directed downwards, the other backwards. Dorsal and abdominal ridges not serrated; no spines on the caudal peduncle. Yost-abdominal photophores in $3_{a}^{y}$ groups, 4 between ventrals and anal, 6 above the anal fin, 4 on the lower edge of caudal peduncle; supra-anal series separated from the proanals by a very short inter: space and from the caudals by a distance equal to $\frac{3}{5}$ the length of the supra-anal series. Dorsal 9. Anal? Pectoral as long as the head.

Chagos Archipelago, Salomon, 400 to 500 fathoms.

A single specimen, $28 \mathrm{~mm}$. in total length.

Five species of Argyropelecus may now be regarded as well established, all of which are represented in the British Museum Collection; they may be distinguished as follows :-

I. Photophores forming a nearly continuous series . . . . . . 1. affinis, Garm., 1899.

II. Postabdominal photophores in 3 groups-preanal, supra-anal, and caudal.

A. Dorsal and abdominal ridges serrated; a double series of spines on the lower surface of caudal peduncle; procoperculum with a single down wardly directed spine 2. aculeatus, C. \& V., 1849. 
B. Dorsal and abdominal ridges entire; no spines on the tail.

1. A single downwardly directed spine at the angle of præoperculum; dorsal fin with 9 rays . . . . . . . 3. olfersii, Cuv, 1829.

2. Two spines at the angle of preoperculum, one directed downwards, the other backwards.

Dorsal with 9 rays; supra-anal photophores separated from the præanals by a very short interspace and from the caudals by a distance which is much less than the length of the supra-anal series . . . Dorsal with 7 or 8 rays; supra-anal photophores separated from the proanals by a distance of more than $\frac{1}{2}$ the length of the supra-anal series and from the caudals by a distance greater than the length of the supra-anal series . . . . . . . . . . 5. hemigymnus, Cocco, 1829.

From this it will be seen that $A$. sladeni is intermediate between $A$. olfersii and A. hemigymmes. It agrees with $A$. olfersii in general form and in the arrangement of the photophores, except that the caudal peduncle is more slender and the supra-anal and caudal series of photophores are more widely separated-characters in which it approaches $A$. hemigymus, which it also resembles in having tro spines at the angle of the præoperculum.

All the species hitherto described have a wide distribution. A. affinis, A. olfersii, and $A$. hemigymms have been recorded from various localities in the Atlantic and Indian Oceans. A. conimus, Garman, 1899, from the Pacific Coast of Panama, appears to be a synonym of $A$. olfersii, and $A$. heathi, Gilbert, 1905, from the Sandwich Islands, seems to be identical with $A$. hemigymmes. Probably $A$. lychmus, Garm., 1899, from the Pacific, will prove to be the same as the North Atlantic $A$. aculeatus, which has also been described by Saurage from the Indian Ocean.

\section{Chanidæ.}

6. Chanos salmoneus, Bl. Schn.

Chagos Archipelago, Diego Garcia.

\section{Scopelidæ.}

7. Neoscopelus macrolepidotus, Jolinson.

Saya de Malha Bank, 300 to 500 fathoms.

S. Su孔rus vurius, Lacep.

Maldives, S. Nilandu, 30 to 36 fathoms, Felidu, 34 fathoms, Kolumadulu, 33 fathoms, and $\mathrm{N}$. Male, 35 fathoms.

9. Saurida nebulosa, C. \& V.

Maldives, S. Nilandu, 36 fathoms, Felidu, 34 fathoms, and N. Male, 35 fathoms.

10. Saurida tumbil, Bl.

Maldives, Suvadiva, 44 fathoms, Felidu, 34 fathoms, and Kolumadulu, 33 fathoms. Cargados Carajos, 28 to 30 fathoms. 


\section{Murænidæ.}

11. Murenu macassariensis, Blkr.

Seychelles Group, Coetivy.

12. Murcen pseudothysoidea, Blki.

Clıagos Archipelago, Peros.

13. Mॅrcena nebulosa, Ahl.

Chagos Archipelago, Peros; Seychelles Group, Coetivy.

14. Muriena pieta, AhI.

Maldives.

15. Wuvanu vichardsoni, Blkr.

Cargados Carajos, 30 fathoms.

16. Murena polyzona, Richarids.

Chagos Archipelago, Salomon.

\section{Anguillidæ.}

17. Ophichthys melanochir, Blkr.

Maldives.

18. Ophisurus colubrinus, Bodd., var. semicinctu, Blkr.

Chagos Archipelago, Peros.

\section{Fierasferidæ.}

19. Fierasfer homei, Richards.

Chagos Archipelago, Diego Garcia. Seychelles Group, 34 fathoms, and Amirante, 39 fathoms. Saya de Malha, 55 fathoms.

20. Fierasfer neglectus, Ptrs.

Chagos Archipelargo, Salomon; Seychelles Group, Coetivy and Amirante, 22 to 85 fathoms.

21. Fierasfer lumbricoides, Blkr

Chagos Archipelago, Salomon.

Scombresocidæ.

22. Exocotus evolans, I.

30 miles W. of Great Chagos Bank; Seychelles.

23. Exocotus nigripinnis, C. \& V.

Chagos Archipelago, Salomon. 


\section{MIngilidæ.}

24. Mrugil ceruleomaculatus, Lacep.

Chagos Archipelago, Diego Garcia.

\section{Fistulariidæ.}

25. Fistularia depressa, Gthr.

Seychelles Group, Amirante.

\section{Solenostomidæ.}

26. Solenostoma cyanopterum, Blkr.

Cargados Carajos, 20 to 30 fathoms.

27. Solenostoma paradoxum, Pall.

Maldives, MLulaku, 27 fathoms.

\section{Syngnathidæ.}

28. Ichthyocampus belcheri, Kaup.

Maldives, Suvadiva, $4 \mathrm{t}$ fathoms.

29. Syngnathus zanzibarensis, Gthr.

Cargados Carajos, 20 to 30 fathoms.

\section{Pegasidæ.}

30. Pegasus druconis, L.

Maldives.

\section{MTacruridæ.}

31. Ifucrurus microstomus, sp. n. (Plate 23. fig. 2.)

Depth of body $\frac{2}{3}$ in the length of head. Snout longer than eye, the diameter of which is $3 \frac{1}{4}$ in the length of head; interorbital width 5 in the length of head. Infraorbital ridges distinct; mouth small, inferior, commencing below the nostrils and ending below the middle of eye, its width $\frac{2}{5}$ the width of head; teeth in bands; barbel less than $\frac{1}{3}$ the diameter of eye; 6 branchiostegals. Anterior dorsal with II 7 rays, the spine serrated; ventrals 8-rayed. Scales imbricate, each with from 5 to 9 equal and parallel keels; S scales between anterior dorsal and lateral line.

Saya de Malha Bank, 300 to 500 fathoms.

A single specimen, $180 \mathrm{~mm}$. in total length.

Allied to M. bairdii, Goode \& Bean, and to M. cequalis, Gthr. 


\section{Berycidæ.}

32. Myripristis parvidens, C. \& V.

Seychelles Group, Coetivy.

33. Holocentrum diadema, Lacep.

Maldives.

34. Holocentrum rubrum, Forsk.

Seychelles Group, Amirante.

\section{Serranidæ.}

35. Epinephelus aryus, Bl. Schn.

Maldives.

36. Epinephelus merra, $\mathrm{Bl}$.

Maldives.

37. Epinephelus fosciatus, Forsk.

Seychelles Group, Coetivy.

38. Epinephelus chlorostigma, C. \& V.

Caregados Carajos, 20 to 30 fathoms.

39. Epinephelus sexfasciutus, C. \& V.

Maldives, Haddumati, 35 fathoms.

10. Anthics cooperi, Regan. (Plate 24. fig. 4.)

Faun. \& Geogr. Mald. \& Lacead. Archipel. i. pt. 3, p. 273 (1902).

Depth of body $2 \frac{1}{2}$ to 3 in the length, length of head $3 \frac{1}{4}$ to $3 \frac{2}{5}$. Snout scaly, convex, shorter than or nearly as long as eye, the diameter of which is 3 (young) or 4 (adult) in the length of head and nearly equal to the interorbital width; lower jaw slightly projecting, scaly; maxillary scaly, extending to below middle (young) or posterior edge (adult) of eye, the width of its distal extremity, in the adult, $\frac{3}{4}$ to $\frac{5}{6}$ the diameter of eye; serrae of proopercle enlarged at angle, especially in the young; sub-and interopercle serrated in the young, the serræ wholly or partly obsolete in the adult; three opercular spines. 26 to 30 gill-rakers on the lower part of the anterior arch. 50 to 52 scales in a longitudinal series, 47 to 49 in the lateral line, 4 between middle dorsal spines and lateral line. Dorsal X 15-16, originating above the opercular cleft, the spines subequal from the fourth, which is $\frac{1}{3}$ (adult) or $\frac{2}{5}$ (young) the leagth of head and considerably shorter than the soft rays; base scaly. Anal III 7; second and third spines subequal. Pectoral as long as or a little longer than the head; outer ray of ventral more or less produced in the aduit. Caudal crescentically emarginate, with the 
lobes more or less produced and pointed in the adult. Reddish brown; edges of scales lighter; a bluish-white stripe from below eye to base of pectorals; fins yellowish.

This species was originally described from a small specimen of $47 \mathrm{~mm}$. from Haddumati. Another of about the same size has since been received from Cargados Carajos, and also some adult specimens (85 to $100 \mathrm{~mm}$. in total length) collected by Mr. F. W. Townsend at Kurrachee. These are included in the amended description given above. The relations of $\mathcal{A}$. cooperi to its nearest allies may be shown thus :-

Snout, interorbital region, and maxillary scaly; lateral line curved, not forming an angle below the hinder dorsal rays. 47 to 52 scales in a longitudinal series, 5 or 6 between first dorsal spine and lateral line, thetween middle dorsal spines and lateral line. Dorsal X 15-17. Anal III 7 .

I. Dorsal spines subequal from the third or fourth, the third not produced.

A. Length of head 3 to $3 \frac{1}{2}$ in the length of the fish.

Maxillary extending to below middle of eye (adult); fourth dorsal spine the length of head; 44 to 46 scales in the lateral line . . . . . . A. hypselosoma, Blkr.

Naxillary extending to below posterior part or posterior edge of eye (adult); fourth dorsal spine $\frac{1}{3}$ (adult) or $\frac{}{5}$ (young) the length of head ; 4.7 to 49 scales in the lateral line.

A. cooperi, Regan.

B. Length of head $3 \frac{4}{5}$ in the length of the fish ; fourth dorsal spine $\frac{3}{5}$ the length of hearl (romer) . . . . . . . . . . . A. teniatus, Klunz.

II. Third dorsal spine prodnced into a short filament . . . . . A.pleurotenia, Blkr.

\section{XENANTHIAS, gen. nov.}

Body compressed; scales large, smooth, ciliated. Lateral line incomplete, ending below the soft dorsal; tube straight, extending nearly the whole length of the exposed part of the scale. Mouth rather large, protractile; no supramaxillary; jaws with villiform teeth and a few small canines; narrow bands of teeth on vomer and palatines; tongue smooth; head scaly, except snout, lower jaw, and lower part of maxillary; proopercle, subopercle, and interopercle serrated; three opercular spines. Gillmembranes separate; 6 or 7 branchiostegals; pseudobranchire present; $3 \frac{1}{2}$ gills. Two dorsals connected at the base with $\mathrm{X}, 14-1$ o rays, the spinous dorsal a little longer than the soft. Anal short, with III 6-7 rays. Cauclal probably subtruncate. Pectoral subsymmetrical, pointed; rays 1.4, all simple, not branched. Ventrals below pectorals, close together, with I 5 rays.

Evidently closely allied to Dactylanthias, Blkr., which has the dorsal fin undivided. From Blecker's figure of $D$. huploductylus it would appear that the lateral line may be only vestigial on the caudal peduncle in that species.

\section{Tenanthias gardineri, sp.n. (Plate 28. fig. 1.)}

Depth of body $2 \frac{1}{3}$ to $2 \frac{1}{2}$ in the length, length of head $2 \frac{1}{2}$ to $2 \frac{2}{3}$. Snout a little shorter than eye, the diameter of which is $3 \frac{1}{2}$ to $3 \frac{3}{4}$ in the length of head and twice the interorbital width. Lower jaw slightly projecting; maxillary extending ixeyond the vertica! 
from posterior edge of eye. 5 or 6 gill-rakers and 2 or 3 rudiments on the lower part of the anterior arch. 27 to 30 scales in a longitudinal series, 16 to 20 in the lateral line, which ends below the middle of the soft dorsal. Dorsal X, 14-15; fourth spine usually longest, $\frac{1}{2}$ the length of head; soft fin scaly at the base. Anal III $6-7$; second spine longest. Pectoral nearly $\frac{3}{4}$ the length of head, extending to above the origin of aual. Ventral $\frac{3}{5}$ the length of head. No markings on head or body; fins pale.

Seychelles Group, Amirante, 25 to 35 fathoms.

Five specimens, the largest $48 \mathrm{~mm}$. in total length.

12. Grammistes sexlineatus, Thunb.

Chagos Archipelago, Salomon.

43. Plesiops nigricans, Rüpp

Seychelles Group, Coetivy.

44. Priacanthus hampur, Forsk.

Seychelles Group, Amirante.

15. Genyoroge bengalensis, Bl.

Seychelles Group, Amirante.

46. Cirrhitichthys oxyrh!nchus, Bllis.

Chagos Archipelago, Salomon.

47. Cirrhitichthys oxycephalus, Blkr.

Maldives.

48. Chilodipterus quinquelineatus, C. \& I.

Chagos Archipelago, Diego Garcia.

49. Apogon variegatus.

? Apogon variegatus, Val., Nour. Ann. Mus. i. 1832, p. 55.

Depth of body $2 \frac{1}{5}$ to $2 \frac{3}{5}$ in the length, length of head $2 \frac{1}{3}$ to $2 \frac{2}{3}$. Snout $\frac{1}{2}$ to $\frac{3}{5}$ as long as eye, the diameter of which is 3 to $3 \frac{1}{4}$ in the length of head; interorbital width $4 \frac{2}{3}$ to $5 \frac{2}{3}$ in the length of head. Jaws equal anteriorly; maxillary extending to below posterior edge of eye, Præoperculum, praopercular ridge, and supraclavicle entire. 8 gill-rakers on the lower part of the anterior arch. 21 or 22 seales in a longitudinal scries; lateral line incomplete, ending below the soft dorsal. Dorsal VII, I 9; third spine longest and strongest, $\frac{1}{2}$ to $\frac{3}{5}$ the length of head; second dorsal scarcely higher than the first, with convex free edge. Anal II 8, the second spine $\frac{1}{3}$ the length of head. Pectoral $\frac{2}{3}$ the length of head; ventrals not reaching the anal. Caudal rounded. Caudal peduncle $1 \frac{1}{2}$ as long as deep. Head and body crossed by 5 or 6 very irregular dark vertical bars and with numerous dark and pale spots; spinous dorsal more or less blackish ; soft dorsal, caudal, and anal with series of small dark spots; ventrals blackish, except near the base. 
Maldives, Suvadiva, 44 fathoms; Chagos Archipelago, Diego Garcia, 10 fathoms.

Six specimens, measuring up to $44 \mathrm{~mm}$. in total length.

Apogon variegatus was originally described from Mauritius.

50. Apogon vittiger.

? Apoyon vittiger, Beun., Proc. Zool. Soc. 1833, p. 32.

Depth of body $2 \frac{4}{5}$ to 3 in length, length of head $2 \frac{2}{3}$. Snout $\frac{2}{3}$ as long as eye, the diameter of which is 3 in the length of head; interorbital width 4 in the length of head. Jaws equal anteriorly; maxillary extending to below the middle of eye. Præoperculum serrated; free edge of second suborbital, præopercular ridge, and supraclavicle denticulated. 14 gill-rakers on the lower part of the anterior arch. 25 scales in a longitudinal series. Dorsal VII, I 9; spines rather slender, the third the longest and slightly more than $\frac{1}{2}$ the length of head; soft dorsal higher than the spinous, the anterior rays the longest, the free edge somewhat convex. Anal II 8 , the second spine $\frac{3}{8}$ the lengtl of head. Pectoral $\frac{2}{3}$ the length of head; ventrals not quite reaching the anal. Caudal rather deeply notched. Caudal peduncle nearly twice as long as deep. A dark longitudinal band from the snout through the eye to the upper part of the caudal peduncle, followed by a dark spot above the lateral line in front of the caudal fin; anteriorly a pale band separating the dark one from the dark colour of the back; spinous dorsal dusky; a more or less distinct dark stripe along the basal part of the soft dorsal and a similar one on the anal.

Seychelles Group, Coetivy.

Two specimens, $72 \mathrm{~mm}$. in total length.

Apogon vittiger, originally described from Mauritius, is allied to $A$. frenutus, Val., and A. kallopterus, Blkr., of the East Indian Archipelago, and has usually been placed as a synonym of the former. Bennett's description is so short that certain identification of his species is impossible, but it is probably the one described above.

51. Apogon punctutus, sp.n. (Plate 24. fig. 1.)

Depth of body $2 \frac{1}{5}$ to $2 \frac{2}{5}$ in the length, length of head $2 \frac{2}{5}$ to $2 \frac{2}{3}$. Snout nearly as long as eye, the diameter of which is $3 \frac{1}{2}$ to $3 \frac{3}{4}$ in the length of head and equal to the interorbital width. Jaws equal anteriorly; maxillary extending to below posterior edge of eye. Præoperculum serrated; præopercular ridge entire, or with one or two projections at the angle; supraclavicle denticulated. 11 gill-rakers on the lower part of the anterior arch. 24 to 26 scales in a longitudinal series. Dorsal VII, I 9 ; spines rather strong, the third and fourth the longest, $\frac{1}{2}$ the length of head; soft dorsal not higher than the spinous, with convex free edge. Anal II 8, the second spine $\frac{2}{7}$ to $\frac{1}{3}$ the length of head. Pectoral $\frac{3}{5}$ the length of head; ventrals nearly reaching the origin of anal. Caudal rounded. Caudal peduncle as long as deep. A dark spot on each scale on the side of the body; dorsal, anal, and ventral fins blackish.

Cargados Carajos, 20 to 30 fathoms.

Four specimens, measuring up to $85 \mathrm{~mm}$. in total length.

The species is allied to $A$. nigripinnis, C. \& V.

SECOND SERIES.-ZOOLOGY, VOL. XII. 


\section{Apogon quinquestriatus, sp. n.}

Depth of body 3 in the length, length of head $2 \frac{3}{4}$. Snout $\frac{2}{3}$ as long as eye, the diameter of which is 3 in the length of head; interorbital width 4 in the length of head. Jaws equal anteriorly; maxillary extending to below middle of eye. Præoperculum serrated; proopercular ridge and supraclavicle entire. 13 or 14 gill-rakers on the lower part of anterior arch. About 24 scales in a longitudinal series. Dorsal VII, I 9 ; spines rather slender, the third the longest and $\frac{1}{2}$ the length of head ; soft dorsal highest anteriorly, the free edge probably slightly concave. Anal II 8 , the second spine $\frac{1}{3}$ the length of head. Pectoral $\frac{2}{3}$ the length of head; ventrals nearly reaching the origin of anal. Caudal probably notched. Caudal peduncle $1 \frac{1}{2}$ as long as deep. A dark longitudinal stripe from the snout through the eye to the end of the middle caudal rays, another from above the eye to the upper part of the caudal peduncle; a median stripe from interorbital region to origin of dor'sal.

Maldives, S. Nilandu, 30 to 36 fathoms.

Two specimens, $46 \mathrm{~mm}$. in total length.

Allied to A. quadrifasciatus, C. \& V., and to A. septemstriatus, Gthr.

53. Apogon taniophorus, sp. n.

Depth of body $2 \frac{3}{4}$ to 3 in the length, length of head $2 \frac{4}{5}$. Snout $\frac{3}{5}$ to $\frac{3}{4}$ as long as eye, the diameter of which is $2 \frac{3}{4}$ to $3 \frac{1}{4}$ in the length of head; interorbital width $4 \frac{1}{2}$ to 5 in the length of head. Jaws equal anteriorly; maxillary extending to below the posterior edge of pupil, or a little beyond. Præoperculum serrated; præopercular ridge and suborbitals entire; supraclavicle denticulated. 12 gill-rakers on the lower part of the anterior arch. 24 scales in a longitudinal series. Dorsal VII, I 9 ; third spine longest and strongest, $\frac{1}{2}$ to $\frac{3}{5}$ the length of head; soft dorsal higher than the spinous, the anterior rays the longest, the free edge concave. Anal II 8 , the second spine $\frac{1}{3}$ to $\frac{3}{8}$ the length of head. Pectoral $\frac{3}{5}$ to $\frac{2}{3}$ the length of head; ventrals extending to the origin of anal. Caudal notched. Caudal peduncle $1 \frac{1}{2}$ to $1 \frac{2}{3}$ as $l o n g$ as deep. 4 dark longitudinal stripes on each side, the uppermost at the base of the dorsal fins, the others terminating on the basal part of the caudal; second stripe originating on the snout and running above the eye and the lateral line; third stripe running from the snout through the eye and the base of the pectoral along the middle of the side, not expanding to form a spot on the caudal peduncle; fourth stripe originating at the lower part of the eye; on the opercular bones the third and fourth stripes are somewhat expanded and very strongly defined; a dark stripe on the basal part of the soft dorsal, a less distinct one on the anal.

Maldives.

Three specimens, the largest $92 \mathrm{~mm}$. in total length.

The species is nearest to $A$. balinensis, Blkr. A specimen from Samoa has recently been figured by Jordan and Seale (Bull. U.S. Fish. Bureau, xxr. 1905, fig. 37) as a colour-variety of $A$. novemfasciatus, C. \& V. 
54. Apogon maculipinnis, sp. n. (Plate 27. fig. 3.)

Depth of body $2 \frac{1}{2}$ in the length, length of head $2 \frac{2}{5}$. Snout $\frac{1}{2}$ as long as eye, the diameter of which is $2 \frac{4}{5}$ in the length of head; interorbital wilth $4 \frac{1}{3}$ in the length of head. Jaws equal anteriorly; maxillary extending a little beyond the middle of eve. Præoperculum serrated; præopercular ridge and supraclavicle entire. 11 gill-rakers on the lower part of the anterior arch. About 21 scales in a longitudinal series. Dorsal VII, I 9; spines of moderate strength, the third the longest and $\frac{1}{2}$ the length of head; soft dorsal higher than the spinous, with convex free edge. Anal II 8, the second spine $\frac{1}{3}$ the length of head. Pectoral $\frac{3}{5}$ the length of head; ventrals reaching the origin of anal. Caudal subtruncate. Caudal peduncle $1 \frac{1}{2}$ as long as deep. Head and body powdered with blackish dots; body with a few irregular spots; upper parts of spinous dorsal blackish; soft dorsal, anal, and ventrals with series of small dark spots; caudal with numerous dark dots.

Maldives, Haddumati, 40 fathoms.

A single specimen, $50 \mathrm{~mm}$. in total length.

Allied to $A$. modestus, Blki.

55. Apogon gardineri, sp. n.

Depth of body $2 \frac{3}{4}$ in the length, length of head $2 \frac{1}{2}$. Snout $\frac{1}{2}$ as long as eye, the diameter of which is $2 \frac{3}{4}$ in the length of head; interorbital width 4 in the length of head. Jaws equal anteriorly; maxillary extending to below middle of eye. Præoperculum serrated; præopercular ridge and supraclavicle entire. 10 gill-rakers on the lower part of the anterior arch. 24 scales in a longitudinal series. Dorsal VII, I 9 ; spines of moderate strength, the third the longest and $\frac{1}{2}$ the length of head; soft dorsal higher than the spinous, with convex free edge. Anal II 8, the second spine nearly $\frac{1}{3}$ the length of head. Pectoral $\frac{3}{5}$ the length of head; ventrals nearly reaching the origin of anal. Caudal slightly notehed. Caudal peduncle $1 \frac{1}{2}$ as long as deep. Faint traces of 3 dark vertical bars, the first below the spinous dorsal, the second below the soft dorsal, the third on the caudal perluncle. Spinous dorsal blackish, except posteriorly ; ventrals blackish at the tip.

Cargados Carajos, 30 fathoms.

A single specimen, $50 \mathrm{~mm}$. in total length.

Allied to $A$. bandanensis, Blkr.

\section{Pristipomatidæ.}

56. Pentapus curtus, Guichen.

Seychelles Group, Amirante, 30 to 80 fathoms.

\section{Pseudochromididæ.}

57. Pseudogramma polyacanthus, $131 \mathrm{kr}$.

Seychelles Group, Amirante, 25 to 35 fathoms. 
58. Pseudoplesiops typus, Blkr.

The first example of this monotypic genus to reach the British Museum was taken at Diamant at a depth of 16 fathoms, and shows that only the first ray of the dorsal and anal fins is a true spine, which is followed in each case by a number of simple articulated rays. Each ventral fin is made up of a slender spine and 4 simple articulated rays. The genus appears to be allied to Pseudochromis and to Plesiops.

Chagos Achipelago, Peros, off Diamant Island.

\section{Centrarchidæ.}

59. Kuhlia teniura, C. \& V.

Seychelles Group, Praslin.

\section{Mullidæ.}

60. Upeneoides tragula, Richards.

Maldives, Mulaku, 27 fathoms.

\section{Chætodontidæ.}

\section{Holacanthus somervillii, sp. n. (Plate 24. fig.6.)}

Depth of body 2 in the length, length of head $3 \frac{3}{4}$. Snout $\frac{3}{4}$ as long as eye, the diameter of which is $2 \frac{3}{4}$ in the length of head and equal to the interorbital width. Præorbital denticulated; præopercular spine $\frac{1}{4}$ the length of head; no spines on lower limb of preoperculum or on interoperculum. 50 scales in a longitudinal series. Dorsal XIV 16; spines increasing in length throughout; length of base of soft-rayed part $1 \frac{3}{4}$ in that of the spinous part. Anal III 17. Soft dorsal and anal obtusely pointed. Caudal rounded. Pectoral nearly as long as the head; ventrals extending to the origin of anal. Dark brownish; a large blackish lumeral spot; body with several irregular narrow dark transverse bars directed somewhat obliquely downwards and forwards, each occupying the whole width of a transverse series of scales, but changing in its course from one series to another; fins blackish, the caudal with a narrow pale edge.

Seychelles Group, Coetivy.

A single specimen, $64 \mathrm{~mm}$. in total length.

Closely allied to $H$. multispinis, Gthr. \& Playf., which has 2 præopercular spines, the upper $\frac{1}{2}$ the length of head, and 3 or 4 interopercular spines.

Named after Comm. Boyle T. Somerville, R.N., who commanded H.MI.S. Sealark during the expedition.

\section{Acanthuridæ.}

62. Acanthurus triostegus, Bl.

Seychelles Group, Coetivy.

\section{Pomacentridæ.}

63. Dascyllus nigripinnis, sp. n. (Plate 24. fig. 5.)

Depth of body $1 \frac{2}{3}$ in the length, length of head $3 \frac{1}{3}$. Snout shorter than eye, the diameter of which is $2_{4}^{3}$ in the length of head and equal to the interorbital width. 
Maxillary scarcely reaching the vertical from anterior edge of eye. Head entirely scaly. 18 gill-rakers on the lower part of anterior arch. 27 scales in a longitudinal series. Dorsal XII 15; spines gradually decreasing from the second, which is $\frac{2}{3}$ the length of head and as long as the longest soft rays. Anal II 14, rounded. Caudal slightly emarginate, with rounded lobes. Pectoral a little shorter than the head; ventrals reaching the origin of anal. Caudal peduncle as long as deep. Brownish grey; each scale with a blue spot; lips blackish; a blackish spot at the base of pectoral; spinous dorsal, ventrals, and anal blackish.

Maldives.

A single specimen, $65 \mathrm{~mm}$. in total length.

Closely allied to D. marginatus, Rüpp., which has a deeper body (depth $1 \frac{1}{2}$ in the length), a smaller eye (diameter $\frac{1}{3}$ the length of head in specinens of $55 \mathrm{~mm}$.), and the soft vertical fins more produced (longest rays of soft dorsal longer than the second spine, upper caudal lobe pointed). D. marginatus also differs somewhat in coloration, as the lips are not blackish, the pectoral spot is larger, and only the upper half of the spinous dorsal and the anterior half of the anal are blackish.

64. Dascyllus melanurus, Blkr.

Maldives, Felidu, 34 fathoms.

65. Dascyllus trimaculatus, Rüpp.

Cargados Carajos, 20 to 30 fathoms.

66. Dascyllus arucuus, I.

Maldives; Chagos Archipelago, Egmont and Salomon.

67. Pomacentrus polylepis, sp.n. (Plate 24. fig. 3.)

Depth of body $2 \frac{3}{5}$ to $2 \frac{4}{5}$ in the length, length of head $3 \frac{2}{5}$ to $3 \frac{3}{5}$. Snout shorter than eye, the diameter of which is 3 to $3 \frac{1}{4}$ in the length of head and equal to the interorbital width. Maxillary extending to the vertical from anterior edge of eye or a little beyond. Snout, anterior part of interorbital region, preorbital, and suborbitals naked. Preoperculum serrated; preorbital and suborbitals entire. 47 to 50 scales in a longitudinal series. Dorsal XIII 11-12; fifth, sixth, and seventh spines the highest, $\frac{1}{2}$ the length of head, a little longer than the longest soft rays. Anal II 12-13. Caudal deeply forked. Pectoral nearly $\frac{3}{4}$ the length of head; ventrals not quite reaching the origin of anal. Caudal peduncle a little longer than deep. Greyish violet, with blue longitudinal stripes along the series of scales; a dark spot at the base of pectoral; rertical fins dusliy.

Cargados Carajos, 20 to 30 fathoms.

Two specimens, 54 and $80 \mathrm{~mm}$. in total length.

Allied to $P$.jerdoni, Day, but differing from all known species of Pomacentrus in the small size of the scales. 


\section{Pomacentrus punctutus, Quoy \& Gaim.}

Maldives, Suvadiva, 43 fathoms, and Haddumati, 40 fathoms.

69. Amphiprion sebr, Blkr.

Maldives, S. Nilandu, 30 fathoms, and N. MTale, 35 fathoms.

70. Amphiprion nigripes, sp.n. (Plate 24. fig. 2.)

Depth of body $2 \frac{1}{4}$ in the length, length of head $3 \frac{1}{2}$. Snout a little shorter than eye, the diameter of which is $3 \frac{2}{5}$ in the length of head and nearly equal to the interorbital width. Maxillary scarcely reaching the vertical from anterior margin of eye. Cheek with 5 series of scales. 12 gill-rakers on the lorver part of anterior arch. 55 scales in a longitudinal series. Dorsal X 17 ; third, fourth, and fifth spines the longest, a little more than $\frac{1}{3}$ the length of head, considerably shorter than the longest soft rays. Anal II 14. Caudal subtruncate. Pectoral nearly as long as the head; ventrals shorter, not reaching the anal. Caudal peduncle as long as deep. Brownish; a faint narrow whitish vertical stripe from nape to suboperculum, just behind the posterior edge of præoperculum; dorsal, caudal, and pectorals pale; ventrals and anal blackish.

Maldives.

A single specimen, $75 \mathrm{~mm}$. in total length.

Allied to A. melcnopus, Blkr., and A. perideraion, Blks., especially to the latter, which differ's markedly iu coloration and has the eye smaller (diameter $3 \frac{3}{4}$ in the length of head and $1 \frac{1}{3}$ in the interorbital width in specimens of $65 \mathrm{~mm}$.) and the caudal peduncle a little deeper than long.

71. Glyphidodon calestinus, C. \& V. Seychelles Group, Praslin.

72. Glyphidodon florulentus, Gthr. Seychelles Group, Coetivy.

\section{Labridæ.}

73. Labroides dimidiatus, C. \& V. Maldives, Felidu, 34 fathoms.

74. Pteragoyus opercularis, Ptrs.

Cargados Carajos, 20 to 30 fathoms.

75. Julis schuonefeldii, Blkr. Maldives, Mulaku, 27 fathoms.

76. Cheilinus ceramensis, Blkr.

Maldives; Seychelles, 37 fathoms. 
77. Cheilinus chlorurus, Bl.

Seychelles Group, Coetivy.

78. Cheilinus arenatus, C. \& V.

Cargados Carajos, 20 to 30 fathoms.

79. Pseudocheilinus evanidus, Jord. \& Everm.

Seychelles Group, Amirante, 25 to 35 fathoms.

Several specimens should apparently be referred to this species, which has recently been described from the Sandwich Islands.

\section{Scaridæ.}

80. Pseudoscarus troscheli, Blkr.

Chagos Archipelago, Peros.

\section{Carangidæ.}

81. Caranx crumenophthalmus, Bl.

Maldives.

\section{Cyttidæ.}

NEOCYTTUS*, Gilchr.

Body deep, strongly compressed; head moderately compressed, the interorbital region broad. Mouth moderate; upper jaw with a narrow band of very small pointed teeth; sometimes a few similar teeth near the symphysis of the lower jaw and on the vomer. 5 or 6 hranchiostegals. Scales small, imbricated, with spiny edges; lateral line complete, curved anteriorly. Dorsal with VII 31-34 rays, the spines strong; anal with III 29-31 rays. Caudal truncate. Pectorals short, obtuse, each with 17-21 rays; ventrals each with I 6 rays, inserted a little behind the base of pectorals, narrowly separated at the base, not folding into a sheath.

Allied to Oreosoma, C. \& V., and Cyttosoma, Gilchrist, which have the ventral fins below the pectorals and more widely separated at the base, and have some or all of the scales juxtaposed and tubercular.

\section{Neocyttus acanthorhynchus, sp. n. (Plate 23. fig. 3.)}

Back elevated, the profile from head to origin of dorsal fin coneave. Depth of body $1 \frac{4}{5}$ in the length, length of head $2 \frac{5}{6}$. Diameter of eye $2 \frac{1}{5}$, interorbital width $2 \frac{3}{5}$ in the length of head. Maxillary extending a little beyond anterior edge of eye; lower jaw as long as eye. Bones of head with spinulose ridges; præorbital ending in a strong antrorse spine, below which are 1 or 2 others directed obliquely downwards; similar spines on the præfrontal above the anterior edge of eye. 15 gill-rakers on the lower

* This genus has recently been established for $N$. rhomboidalis, from decp water off the const of S. Africa, which has smaller scales than $N$. accunthorkynchus and no strong spincs on the snout. 
part of the anterior arch. 75 scales in a longitudinal series; lateral line becoming straight below the middle of soft dorsal. Dorsal VII 31; second spine longest, as long as the eye, a little longer than the longest soft rays. Anal III 29; first spine longest, $\frac{3}{4}$ the longest dorsal spine. Pectorals short; ventrals extending to first soft ray of anal. Caudal rounded. Caudal peduncle deeper than long. Brownish; fins blackish.

Saya de Malha Bank, 450 fathoms.

A single specimen, $125 \mathrm{~mm}$. in total length.

\section{Pleuronectidæ.}

83. Brachypleura anthosticta, Gthr.

Maldives, Suvadiva, 11 fathoms, and Mulaku, 27 fathoms.

S1. Samaris maculatus, Gthr.

Maldives, Suvadiva, 45 fathoms.

S5. Pseudorhombus ocellatus, Gthr.

Saya de Malha Bank, 123 fathoms.

86. Platophrys pantherinus, Rüpp.

Maldives, Suvadiva, 48 fathoms, and S. Nilandu, 30 and 36 fathoms; Scychelles Group, Amirante, 30 fathoms.

87. Platophrys pavo, Blkr.

Chagos Archipelago, P'eros.

SS. Platophrys ovalis, sp. 11. (Plate 27. fig. 6.)

Depth of body about $1 \frac{2}{5}$ in the length, length of head $3 \frac{1}{2}$ to $3 \frac{4}{5}$. Snout much shorter than eye, the diameter of which is $\mathbf{3}$ in the length of head; lower eye scarcely in advance of the upper; interorbital width a little more (largest specimen) or a little less than the diameter of eye. Males with a spine on the snout; no other spines on the head. Maxillary $\frac{1}{4}$ the length of head, scarcely reaching the vertical from the anterior edge of eye. 6 short gill-rakers on the lower part of anterior arch. Scales very small, adherent. Dorsal 88-92. Anal 66-70. Pectoral of the eyed side with the upper 2 or 3 rays produced ( $\left.o^{*}\right), 1 \frac{1}{2}$ as long as the head; pectoral of the blind side rather more than $\frac{1}{2}$ the length of head. Greyish, clouded with darker; a dark spot on the lateral line; head and body with numerous small spots, some blue enclosed in brownish rings, other's white with dark centres; posterior part of caudal blackish.

Seychelles Group, Amirante, 30 fathoms.

'Three specimens, measuring up to $95 \mathrm{~mm}$. in total length.

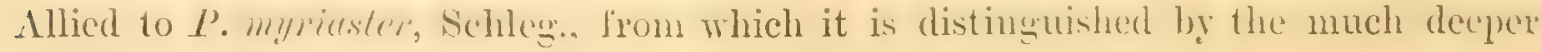
borly, smaller mouth, \&c. 
89. Platophrys circularis, sp.n. (Plate 26. fig. 3.)

Evidently closely allied to the preeding, but with a deeper body (depth $1 \frac{1}{4}$ in the length), a shorter head (4 in the length of the fish;, and a smaller eye (diameter nearly $\frac{1}{4}$ the length of head, nearly equal to the interorbital width). Dorsal 90. Anal 66 . Pectoral of the eyed side $\frac{3}{5}$, of the blind side $\frac{2}{5}$ the length of head. Body with dark spots and rings; a dark spot on the lateral line.

Seychelles Group, Amirante, 22 to 85 fathoms.

A single specimen, $38 \mathrm{~mm}$. in total length.

90. Scaops pæcilurus, Bllir.

Maldives, Suvadiva, 34 and 44 fathoms.

91. Sccops latifrons, sp. n. (Plate 25. fig. 3.)

Depth of body $1 \frac{4}{5}$ to 2 in the length, length of heal $3 \frac{1}{2}$ to 4 . Snout as long as or shorter than eye, the diameter of which is 3 to 4 in the length of liead; anterior edge of upper eye above the middle of the lower one. Interorbital width 1 to $1 \frac{1}{2}(\delta)$ or $\frac{1}{2}$ to $\frac{2}{3}(q)$ the diameter of eye. Males with a spine on the snout; no other spine on the head. Maxillary a little more than $\frac{1}{3}$ the length of head, extending to below anterior $\frac{1}{4}$ of eye. 6 to 8 gill-rakers on the lower part of the anterior arch. Scales not very adherent, finely ciliated on the eyed side, eycloid on the blind side; about 40 in a longitudinal series. Dorsal 80-90. Anal 58-67. Dorsal and anal fins ending just before the caudal, which is rounded. Pectoral of the eyed side $\frac{9}{3}$, of the blind side $\frac{2}{5}$ to $\frac{1}{2}$ the length of head. Traces of dark spots and markingrs on body and vertical fius.

Maldives, 27 to 44 fathoms; Seychelles, 37 fathoms; Saya de Malla Bank, 17 fathoms; Cargados Carajos, 20 to 30 fathoms.

Thirteen specimens, measuring up to $100 \mathrm{~mm}$. in total length.

In this species the males differ from the females in the presence of a spine on the snout, the broader interorbital region, and the body usually a little deeper.

92. Sccops macrolepis, sp. n. (Plate 27. fig. 4.)

Depth of body $1 \frac{5}{6}$ in the length, length of head $3 \frac{4}{5}$. Snout shorter than eye, the diameter of which is $3 \frac{1}{3}$ in the length of head and a little less than the interorbital width ; anterior edge of upper eye above anterior part of the lower one. Male with a spine on the snout, one above the lower eye and one in front of the upper eye. Mtaxillary a little more than $\frac{1}{3}$ the length of head, extending to below anterior $\frac{1}{4}$ of eye. 6 gill-rakers on the lower part of anterior arch. Scales not very adherent, cycloid or feebly ciliated on the eyed side, eycloid on the blind side; 40 scales in a longitudinal series. Dorsal S4. Anal 60. Dorsal and anal fins ending just before the eaudal, which is rounded. Pectoral of the eyed side with the upper ray slightly produced (in the male), scarcely longer than the head; pectoral of the blind side nearly $\frac{1}{2}$ the length of head. Coloration uniform.

Cargados Carajos, 20 to 30 fathoms.

One specimen, a male, $72 \mathrm{~mm}$. in total length.

SECOND SERIES.-ZOOLOGY, VOL. XII. 


\section{Scrops maldivensis, sp. n. (Plate 25. fig. 1.)}

Depth of body about 2 in the length, length of head $3 \frac{2}{3}$ to 4 . Snout shorter than eye, the diameter of which is 3 in the length of head; lower eye a little in alvance of the upper. Interorbital width nearly $\frac{3}{4}(0)$ or less than $\frac{2}{5}(q)$ the diameter of eye. Males with a spine on the snout; no other spines on the head. MLaxillary $\frac{1}{3}$ the length of head, extending a little beyond the anterior edge of eye. $8 \mathrm{or}^{\circ} 9$ gill-rakers on the lowrer part of the anterior arch. Seales deciduous, about 40 in a longitudinal series. Dorsal 70-76. Anal 53-58. Dorsal and anal fins ending just before the caudal, which is rounded. Pectoral of the eyed side with the upper ray produced and $1 \frac{1}{3}$ the length of head ( $\sigma^{\circ}$ ) or without produced rays and as long as the head ( $f$ ); pectoral of the blind side less than $\frac{1}{2}$ the length of head.

Maldives, 27 to 4.4 fathoms.

Three specimens, measuring up to $70 \mathrm{~mm}$. in total length.

\section{Sccops filimanus, sp. n. (Plate 25. fig. 2.)}

Depth of body $1 \frac{t}{5}$ to 2 in the length, length of head $3 \frac{1}{3}$ to $3 \frac{3}{4}$. Snout shorter than eye, the diameter of which is 3 in the length of head and equal to or a little less than the interorbital width; anterior edgge of upper eye above middle of the lower one. Males with an antrorse spine on the snout and 1 or 2 in front of the upper eye; 1 or 2 spines above the lower eye and sometimes 1 or 2 very small ones below the upper eye. Naxillary a little more than $\frac{1}{3}$ the length of head, extending to below anterior $\frac{7}{4}$ of eye. 7 gill-rakers on the lower part of the anterior arch. 10 scales in a longitudinal series. Dorsal 78-80. Anal 62. Dorsal and anal fins ending just before the caudal, which is rounded. Pectoral of the eyed side with the upper ray produced and longer than the head $\left(\sigma^{*}\right)$; pectoral of the blind side nearly $\frac{1}{2}$ the length of head. More or less distinct dark spots and markings.

Maldives, 27 to 14 fathoms.

Two specimens, $62 \mathrm{~mm}$. in total length.

\section{Scaops sechellensis, sp. n. (Plate 2\%. fig. 5.)}

Depth of body $2 \frac{1}{5}$ in the length, length of head $3 \frac{3}{5}$. Snout shorter than eye, the diameter of which is $3 \frac{1}{2}$ in the length of head and equal to the interorbital width. Anterior edge of upper eye above posterior part of lower one. Males with a spine on the snout, one in front of and one above the lower eye, one in front of and one below the upper eye. Maxillary a little more than $\frac{1}{3}$ the length of head, extending to below anterior $\frac{1}{4}$ of eye. 6 gill-rakers on the lower part of the anterior arch. 40 scales in a longitudinal series. Dorsal 82. Anal 63. Dorsal and anal fins ending just before the caudal, which is rounded. Pectoral of the eyed side with the upper ray produced and longer than the head ( $\left.\sigma^{*}\right)$; pectoral of the blind side less than $\frac{1}{2}$ the length of head. Dark spots or markings on body and fins.

Seychelles, 37 fathoms.

A single specimen, $72 \mathrm{~mm}$. in total length. 
96. Enyyprosopon intermedius, Blkr.

Maldives, Suvadiva, 44 fathoms, and Felidu, 34 fathoms; Chagos Archipelago, Diego Garcia, 10 fathoms; Seychelles, 37 fathoms.

97. Arnoglossus malhensis, sp.n. (1'late 26. fig. 2.)

Depth of body $2 \frac{4}{5}$ in the length, length of head 4 . Snout as long as eye, the diameter of which is 4 in the length of head; posterior edge of lower eye slightly behind the middle of the upper; interorbital region slightly concave, scaly, its width $\frac{3}{5}$ the diameter of the lower eye. Lower jaw more than $\frac{1}{2}$ the length of head. 11 gill-rakers on the lower part of the anterior arch. Dorsal 112. Anal 92. Caudal rounded. Left pectoral more than $\frac{1}{2}$, right, pectoral less than $\frac{1}{3}$ the length of head. 96 scales in the lateral line. Uniformly yellowish.

Saya de Malha Bank, over 123 fathoms.

A single specimen, $175 \mathrm{~mm}$. in total length.

98. Achirus poropterus, Bikr.

Maldives, Mulaku, 27 fathoms.

99. Cynoglossus kopsii, Blkx.

Seychelles Group, Amirante, 30 fathoms.

100. Cynoglossus brachycephalus, Blkr.

Maldives, Mulaku, 27 fathoms; Cargados Carajos, 20 to 30 fathoms.

101. Cynoglossus sealarki, sp.n. (Plate 26. fig. 1.)

Depth of body 4 in the length, length of head 5. Snout $\frac{1}{3}$ the length of head. Diameter of eye 7 to 8 in the length of head and 2 to 3 times the interorbital width. A single tubular nostril in front of the lower eye. Maxillary extending to below the middle of eye, rostral hook to below the mandibulary symplysis. Three lateral lines on the left side; scales ctenoid on the left side, cycloid on the right; 65 to 70 scales in a longitudinal series, 10-12 between the upper and middle lateral lines. Dorsal 108-116. Anal 90-95. Uniformly brownish.

Saya de Malha Bank, over 123 fathoms.

Four specimens, measuring up to $190 \mathrm{~mm}$. in total length.

Named after H.M.S. Sealark.

102. Aphoristia wood-masoni, Alc.

Saya de Malha Bank, over 123 fathoms.

\section{Scorpænidæ.}

103. Sebastes strongensis, C. \& V.

Maldives; Chagos Archipelago, Salomon and Egmont. 
101. Scorpenopsis diabolus, C. \& V.

Seychelles Group, Amirante, 30 fathoms.

POGONOSCORPIUS, gell. nov.

Differs from Scorpcenopsis, Heck, in having a well-developed mental barbel and in the strongly compressed head and body.

\section{Pogonoscorpius sechellensis, sp. n. (Plate 28. tig. «.)}

Depth of horly $2 \frac{1}{2}$ in the length, length of head $2 \frac{1}{4}$. Snout longer than postorbital part of head, with concave profile; diameter of eye $5 \frac{1}{2}$ in the length of head and greater than the interorbital wilth; lower jaw projecting; praoperculum with 3 spines. Scales small, probably about 60 in a lougitudinal series. Dorsal XII 10; fourth spine longest, $\frac{2}{5}$ the length of head. Anal III 5 ; third spine longest. Pectoral broad, rounded, of 18 simple rays, cxtending to above the anal spines; ventrals close together, inserted below the pectorals, not reaching the anal. Caudal rounded. Yellowish; fins tinged with redclish.

seychelles, 37 fathoms.

A single specimen, $65 \mathrm{~mm}$. in total length.

100. Trenionotus triacunthus, Lacep.

Chagos Archipelago, Salomon.

107. Pterois zebra, C.\& V.

Maldives, Haddumati and Kóolumadulu, 35 fathoms; Seychelles Group, Amirante, 20 to 35 fathoms.

108. Pterois antenuata, Bl.

Seychelles, 37 fathoms; Cargados Carajos, 20 to 30 fathoms.

109. Pterois volitens, L.

Maldives; Cargados Carajos, 20 to 30 fathoms.

110. Minous longimanus, sp. n. (Plate 28. fig. 2.)

Depth of body equal to the length of head, $2 \frac{2}{3}$ in the length of the fish. Snout longer than eye, the diameter of which is $3 \frac{1}{2}$ in the length of head and $1 \frac{1}{3}$ the interorbital width. Maxillary extending to below anterior $\frac{1}{4}$ of eye. Preorbital with a pair of spines; præoperculum with 6 spines, the second very strong and nearly as long as the eye, the fifth and sixth obtuse projections of the lower limb, each with 3 or 4 denticulations. Dorsal X 11, the spines strong, subequal from the second, which is $\frac{1}{2}$ the length of head. Anal 11. Pectoral extending to last ray of anal. Caudal truncate. Pale brownish; dorsal posteriorly with oblique dark stripes; tip of pectoral, margin of anal, and posterior and lower margins of caudal blackish. 
Saya de Malha Bank, 47 fathoms.

A single specimen, $92 \mathrm{~mm}$. in total length.

The long pectoral and the peculiar armature of the preoperculum distinguish this species from others of the genus.

1.11. Minous monodactylus, Bl. Schn.

Maldives, S. Nilandu and N. Male, 35 and 36 fathoms.

112. Pelor didectylum, Pall.

Maldives, Suvadiva, 30 fathoms.

113. Amblyapistus macraconthus, Blkx.

Maldives, Suvadiva, 30 fathoms.

114. Prosopodasys leucoyaster, Richards.

Seychelles Group, Amirante, 30 fathoms.

115. Cocotropus roseus, Day.

Maldives, N. Male, 35 fathoms.

116. Cocotropus dermacunthus, Blkr.

Seychelles, 37 fathoms.

117. Synanceia verrucosa, Bl. Schm.

Maldives.

118. Cavacunthus maculatus, Gray.

Maldives; Chagos Archipelago, Salomon.

119. Caracunthus unipinua, Gray.

Chagos Archipelago, Salomon.

\section{Platycephalidæ.}

120. Platycephalus asper, C. \& V.

Maldives, Mulaku, 27 fathoms, and N. Male, 35 fathoms.

121. Platycephalus tubevoulatus, C. \& V.

Maldives, Kolumadulu, 35 fathoms, and Haddumati, 40 fathoms.

12:. Platycephalus subfasciatus, Gthr.

Maldives, Mulaku, 27 fathoms. 
123. Platycephalus cooperi, sp.n. (Plate 29. fig. 5.)

Depth of body about 6 in the length, length of head about $2 \frac{2}{3}$. Snout longer than eye, the diameter of which is $3 \frac{1}{2}$ to $4 \frac{1}{4}$ in the length of head and about 4 times the interorbital width. Maxillary extending to below anterior $\frac{1}{4}$ of eye. A more or less developed spine in the middle of each bone of the upper surface of the cranium and also on the preorbital and first suborbital; supraorbital ridges serrated; second suborbital with a serrated ridge; three preopercular spines, the upper $\frac{1}{2}$ to $\frac{3}{4}$ the diameter of eye. $5 S$ to 65 scales in a longitudinal series; anterior 5 to 8 scales of the lateral line spiniferous. Dorsal IX, 11-12. Anal 11. Caudal subtruncate. Ventrals extending to third or fourth ray of anal. Spinous dorsal blackish superiorly; pectorals and ventrals obscurely spotted.

Seychelles Group, Amirante, 30 fathoms; Cargados Carajos, 20-30 fathoms.

Seven specimens, the largest $200 \mathrm{~mm}$. in total length.

Named after Mr. C. Forster Cooper, M.A., who accompanied Mr. Gardiner on his expeditions.

124. Platycephalus pristiger, C. \& V.

Seychelles Group, Amirante, 30 fathoms.

125. Platycephalus oligolepis, sp. n. (Plate 29. fig. 4.)

Depth of body $5 \frac{2}{3}$ in the length, length of head $2 \frac{2}{3}$. Breadth of head $1 \frac{2}{5}$ in its length. Snout as long as eye, the diameter of which is $3 \frac{1}{2}$ in the length of head and 4 times the interorbital width. Maxillary extending to below anterior $\frac{1}{3}$ of eye; vomerine teeth in 2 separate patches. Tead with numerous, compressed, curved spines; two pairs on the snout, 3 in front of each orbit, $10 \mathrm{or}^{2} 11 \mathrm{on}$ each supraorbital ridge, which is followed on each side by a group of 4 ; a spine on each parietal, $201^{\circ} 3$ behind the middle of each orbit, 2 on each supratemporal, a series of 3 on each post-temporal. Suborbital ridge spinate throughout, ending in a præopercular spine of moderate length, below which are 2 others. T'wo opercular spines and one on the clavicle. 5 gill-rakers on the lower part of the anterior arch. 31 scales in a longitudinal series; only the anterior 3 or 4 . scales of the lateral line spiny. Dorsal IX, I 10. Anal 11. Ventrals extending to the fourth or fifth ray of anal. Caudal subtruncate. A dusky spot on each ventral fin.

Cargados Carajos, 20 to 30 fathoms.

A single specimen, $100 \mathrm{~mm}$. in total length.

126. Platycephalus pedimacula, sp. n.

Closely allied to the preceding, differing as follows:- Four spines in front of each orbit; supraorbital ridge entire anteriorly, serrated posteriorly, followed by a series of 3 spines; 2 spines on each parietal, a series of 4 or 5 behind the middle of each orbit. Suborbital ridge less strongly serrated than in $P$. oligolepis (a series of about 26 serrxe in this species instead of 17 as in the preceding one).

Maldives, Kolumadulu, 35 fathoms.

A single specimen, $62 \mathrm{~mm}$, in total lengtl. 
127. Platycephalus grandisquamis, sp. n.

Depth of body $5 \frac{1}{2}$ in the length, length of head $2 \frac{1}{2}$. Snout a little shorter than eye, the diameter of which is 3 in the length of head and 4 times the interorbital width. M Laxillary extending to below anterior $\frac{1}{3}$ of cye; vomerine teeth in 2 separate patches. Head with several spines; 2 on the snout, 1 or 2 in front of each orbit; suprabrital ridges serrated except anteriorly; behind them on each side a more or less regular transverse series of 3 or 4 spines, which are followed by a larger spine on each parietal, with a small one behind it; a serrated lidge behind the middle of each orbit; a series of 3 post-temporal spines; suborbital ridge serrated throughout, ending in a praopercular spine of moderate length, below which are two others. Two opercular spines and one on the clavicle. I gill-rakers on the lower part of the anterior arch. 30 scales in a longitudinal series; only the anterior 3 or 4 scales of the lateral line spinate. Dorsal IX, I 10. Anal 11. Ventrals extending to the fourth anal ray. Caudal subtruncate. Brownish, with dusky bars or marblings; pectoral blackish posteriorly in its lower half; ventral with 2 blackish cross-bars, one near its tip.

Seychelles Group, Amirante, 30 fathoms.

A single specimen, $73 \mathrm{~mm}$. in total length.

The three preceding species are allied to the Japanese $P$. spinosis, Schleg., and $P$. macrolepis, Blkr., and differ from others of the genus in the large size of the scales.

\section{Hoplichthyidæ.}

128. Hoplichthys acunthopleurus, sp.n. (Plate 28. fig. 5.)

Length of head $3 \frac{1}{3}$ to $3 \frac{1}{2}$ in that of the fish. Snout slightly longer than eve. the diameter of which is $3 \frac{2}{3}$ in the length of head. Interorbital region very narrow, bordered by denticulated ridges, all the ridges on the head denticulated. Maxillary extending to below anterior margin of eye or a little beyond. 12 gill-rakers on the lower part of the anterior arch. 27 scutes in a longitudinal series; each scute with a well-developed spine and a second very small spine below it. Dorsal VI, 15; spinous dorsal scarcely ligher in the male than in the female, the spines not produced; second dorsal, in the male, with ali the rays produced into filaments, increasing in length from the first to the third, which is nearly as long as the head, thence decreasing to the fifth and again increasing to the seventh and eighth, which are as long as the third, thence decreasing to the tenth, and again from the twelfth to the last. Anal 17. Caudal truncate.

Saya de Malha Bank, over 123 fathoms.

Two specimens, of \& ㅇ, $180 \mathrm{~mm}$. in total length.

This species is very near to the recently described $I$. citrims, Gilbert, from the Sandwich Islands, males of which have the first dorsal spine produced and filamentous, and only the four anterior rays of the second dorsal produced into filaments.

The name Hoplichthys gilberti may be given to the species described from Japan by Gilbert as H. langsdorfii, C. \& V., and which differs from II. citrime in having none of the rays produced in the males. I have examined several specimens of the true H. langsdorfii, in which each lateral scute bears two strong subequal spines. 


\section{Triglidæ.}

129. Lepidotrigla alcocki, sp. n. (Plate 28. fig. 4.)

Depth of body 4 in the length, length of head 3. Snout longer than eye, the diameter of which is $3 \frac{2}{3}$ in the length of head and less than the depth of the suborbitals. No transverse groove behind the concave interorbital region, the width of which is 6 to $6 \frac{1}{2}$ in the length of head. Proorbitals forming a pair of rounded projections, each margined with 7 to 9 spines; a pair of spines above the anterior edge of each eye. Maxillary not quite reaching to below the eye. 62 to 63 scales in the lateral line, which is unarmed; 24 or 25 spiny plates at the base of the dorsals. Dorsal IX, 15-16; first spine serrated, third longest, $\frac{1}{2}$ the length of head. Anal 16. Caudal slightly emarginate. Pectoral extending to above fourth anal ray, ventrals to origin of anal. Inner surface of pectoral blackish, crossed by a broken oblique white stripe and with a pale edge which is broadest below.

Saya de Malha Bank, over 123 fathoms.

'T'wo specimens, $160 \mathrm{~mm}$. in total length.

I have named this species after Dr. A. Alcock, F.R.S., in recognition of his valuable work on the deep-sea fishes of the Indian Ocean.

130. Peristethus serrulatus, Alcock.

Saya de Malha Bank, over 123 fathoms.

\section{Dactylopteridæ.}

131. Dactylopterus orientalis, C. \& V.

Cargados Carajos, 20 to 30 fathoms.

\section{Gobiidæ.}

132. Gobiomorphus cinctus, sp. n.

Depth of body $3 \frac{2}{3}$ in the length, length of head 3. Head a little deeper than broad, nearly $1 \frac{1}{2}$ as long as deep. Snout shorter than eye, the diameter of which is 3 in the length of head; interorbital space narrow. Mouth oblique; lower jaw projecting; maxillary extending to below anterior $\frac{1}{4}$ of eye. Head naked; about 33 scales in a longitudinal series on the body. Dorsal VI, I 11. Anal I 9. Pectoral $\frac{3}{4}$ the length of head; ventrals extending to the anal. Caudal rounded. Yellowish; head and body crossed by 10 or 11 brownish vertical bars with dark edges.

Chagos Archipelago, Salomon.

Two specimens, $28 \mathrm{~mm}$. in total length.

133. Asterropteryx monacunthus, sp.n.

Depth of body 3 to $3 \frac{1}{2}$ in the length, length of head 3. Snout shorter than eye, the diameter of which is 3 in the length of head; interorbital space narrow. Mouth rather small, oblique; jaws equal anteriorly; maxillary extending to below anterior $\frac{1}{4}$ of eye. A single, rather strong spine at the angle of the prooperculum. Head scaly, except the snout; scales on the body large, rounded, ciliated, 22 or 23 in a longitudinal series. 
Dorsal VI, I 9 ; dorsal spines produced into filaments, the third the longest, when laid back nearly reaching the caudal fin. Anal I 8. Pectoral longer than the head; ventrals extending beyond the origin of anal. Caudals rounded. Vertical fins dusky; a dark spot on the upper part of the base of pectoral.

Seychelles Group, Amirante, 30 fathoms.

Three specimens, measuring up to $35 \mathrm{~mm}$, in total length.

134. Eleotris lantzii, Thomin.

Chagos Archipelago, Peros.

135. Gobius nebulopunctatus, C. \& V.

Chagos Archipelago, Salomon; Seychelles Group, Coetivy.

136. Gobius semidoliatus, C. \& V.

Maldives, N. Male, 35 fathoms.

137. Gobius ophthalmotania, Blkr.

Maldives, N. Male, 36 fathoms, and S. Nilandu, 35 fathoms.

138. Gobius ornatus, Rüpp.

Maldives, 27 to 36 fathoms.

139. Cryptocentrus octofasciatus, sp. n. (Plate 29. fig. 2.)

Depth of body $4 \frac{1}{2}$ in the length, length of head $3 \frac{2}{3}$. Breadth of head a little less than its depth, which is $\frac{2}{3}$ of its length. Snout declivous, as long as the eye, the diameter of which is $4 \frac{1}{2}$ in the length of head; interorbital space narrow. Jaws equal anteriorly; maxillary extending to below posterior edge of eye; teeth in bands, the outer series enlarged; a pair of canines in the upper jarr. Suboperculum produced forward into a spine. Head naked; body covered with small cycloid scales, about 75 in a longitudinal series. Dorsal VI, I 10; spines slightly projecting beyond the membrane, the third longest, $\frac{3}{4}$ the length of head, a little longer than the fourth, which is equal to the longest soft rays. Anal I 9. Caudal rounded, $\frac{2}{7}$ the length of the fish. Pectorals and ventrals subequal in length, a little shorter than the head. Body with 8 dark vertical bars separated by 7 pale stripes and with scattered pale blue spots; blue spots on head and anterior parts of body arranged round some small rounded blackish spots; similar blackish spots in two irregular series on the dorsal fins.

Chagos Archipelago, Diego Garcia.

A single specimen, $75 \mathrm{~mm}$. in total lengtl.

Very closely allied to C. meleagris (Ehrenberg), C. \& V. (Gobius cryptocentrus, C. \& V.), figures of which show the body crossed by 10 pale stripes instead of 7 , the pale blue spots smaller and more numerous, and no black spots on the head or body.

140. Hoplopomus caninoides, Blkr.

Maldives, 27 to 36 fathoms.

This species, originally described from the East Indian Arehipelago, is also represented. SECOND SERIES.-ZOOLOGY, VOL. XII. 
in the British Museum by specimens from the Persian Gulf, collected by Mr. F. W. Townsend, which I formerly determined as Gobius hoplopomus, C. \& V. (H. pulcher, Ehrenberg): The genus Hoplopomus, Ehrenb., 1837 (Cuv. \& Val. Hist. Nat. Poiss. ix. p. 66), differs from Gobius in having the first ray of each dorsal fin a pungent spine.

\section{Hoplopomus acanthistius, sp.n. (Plate 29. fig. 3.)}

Depth of body equal to or a little less than the length of head, which is $3 \frac{3}{5}$ to $3 \frac{4}{5}$ in the length of the fish. Head twice as long as broad, but only a little longer than deep. Snout declivous, shorter than the eye, the diameter of which is 3 in the length of head; interorbital space narrow. Jaws equal anteriorly, or the lower slightly projecting; maxillary extending to below anterior $\frac{1}{3}$ of eye; a pair of small lateral canines in the lower jaw. Posterior edge of prapereulum with 1 or 2 short spinous projections near the angle. Head naked; 10 to 12 small scales in a series from occiput to origin of dorsal fin; scales on the body large, ciliated, 28 to 30 in a longitudinal series. Dorsal VI, I 10 ; first ray of each fin a short, stout, pungent spine; spinous dorsal, in the female, ahout as high as the soft dorsal, in the male more elevated and with the rays, except the first, produced into filaments, the fourth and fifth the longest, as long as the head. Anal I 10. Caudal rounded or doubly truncate. Pectoral $\frac{3}{4}$ the length of head; ventrals extending to the vent ( $q$ ) or origin of anal ( $\left.\delta^{*}\right)$. A series of dark spots on the middle of the side, ending at the base of the caudal; a fer dark spots on the upper part of the body; fins nearly immaculate (in spirit), but traces of 1 or 2 series of rings on the lower part of the second dorsal and of stripes on the anal.

Maldives, Mulaku, 27 fathoms.

Four specimens, measuring up to $70 \mathrm{~mm}$. in total lengtl.

This species is very close to $H$. notacanthus, Blkr., which appears from Bleeker's description to have larger scales on the nape and a ray less in the second dorsal fin.

\section{Gobiopterus modestus, sp.n. (Plate 29. fig. 1.)}

Depth of body equal to length of head, 3 to $3 \frac{1}{2}$ in the length of the fish. Head naked, as long as deep. Snout short; eye small. Mlouth very oblique, not extending to below the eyes. About 24 scales in a longitudinal series. Dorsal VI, I 9. Anal I 9. Dorsal and anal fins subequal in height, the longest rays about $\frac{1}{2}$ the length of head. Pectoral nearly as long as the head; ventrals much shorter. Caudal rounded. Blackish grey.

Chagos Archipelago, Egmont and Salomon.

Several specimens, the largest $40 \mathrm{~mm}$. in total length.

\section{Champsodontidæ.}

143. Champsodon sechellensis, sp. n. (Plate 31. fig. 2.)

Depth of body $4 \frac{1}{2}$ to $4 \frac{2}{3}$ in the length, length of head $3 \frac{3}{5}$. Snout as long as or a little longer than eye, the diameter of which is 4 to $4 \frac{1}{3}$ in the length of head and greater than the interorbital width. Præmaxillaries with a double notch anteriorly; maxillary extending beyond the vertical from posterior edge of eye; distance from tip of snout to 
extremity of maxillary $\frac{3}{5}$ the length of head; least distance between eye and maxillary $\frac{1}{2}$ to $\frac{3}{5}$ the diameter of eye; proopercular spine longer than in the other species, extending much more than $\frac{1}{2}$ the distance from its base to the vertical from the base of pectoral; 10 or 11 gill-rakers on the lower part of the anterior arch. Dorsal V, I 19; second spine a little more than $\frac{1}{3}$ the length of head; distance between origins of dorsals $\frac{2}{5}$ the distance from tip of snout to origin of first dorsal. Anal I 17; origin nearly equidistant from tip of snout and base of caudal. Pectoral a little more than $\frac{2}{5}$ the length of head, ventrals $\frac{4}{5}$ to $\frac{5}{6}$ the length of head, extending to the vent. Silvery; back darker; fins pale.

Seychelles, 37 fathoms.

Two specimens, 70 and $80 \mathrm{~mm}$. in total length.

\section{Champsodon microphthalmus, sp.n. (Plate 31. fig. 3.)}

Depth of body 5 in the length, length of head $3 \frac{1}{2}$. Snout $1 \frac{1}{2}$ as long as eye, the diameter of which is 6 in the length of head and equal to the interorbital width. Præmaxillaries with a double notch anteriorly; maxillary extending beyond the vertical from posterior edge of eye; distance from tip of snout to extremity of maxillary $\frac{3}{5}$ the length of head; least distance letween eye and maxillary equal to the diameter of eye; præopercular spine of moderate length; 9 or 10 gill-raliers on the lower part of the anterior arch. Dorsal IV-V, I 19 ; second spine $\frac{1}{3}$ the length of head; distance between origins of dorsals $\frac{2}{5}$ or a little less than $\frac{2}{5}$ the distance from tip of snout to origin of spinous dorsal. Anal I 17; origin nearel to tip of snout than to base of caudal. Pectoral a little more than $\frac{2}{5}$ the length of head; ventrals $\frac{4}{5}$ the length of head, extending to the origin of anal. 'lraces of dark spots on the upper part of the body; upper part of spinous dorsal sometimes blackish.

Maldives: Suvadiva, 30 fathoms, and Mulaku, 27 fathoms.

Three specimens, 55 to $60 \mathrm{~mm}$. in total length.

The fishes of the genus Champsodon have usually been referred to a single species, viz. C. vorax, Günth., but a second species has recently been described by Gilbert from the Sandwich Islands. In addition to the two species described above and the original C. vorax, the type of which is redescribed below, four species of Champsodon are represented in the British Museum collection and are now described as new to science. The fishes of this genus may be distinguished by means of the following key :-

I. Præmaxillaries without anterior notch ; maxillary extending to the vertical from posterior edge of eye or a little beyond . . . . . . guentheri, sp. n.

II. Promaxillaries with a double notch anteriorly; maxillary extending beyond the vertical from posterior edge of eye.

A. Distance between origins of dorsals much more than $\frac{1}{3}$ of the distance from tip of snout to origin of spinous dorsal.

1. Præopercular spine strong, extending considerably more than $\frac{1}{2}$ the distance from its base to the vertical from the base of pectoral . . sechellensis, sp. $n$. 
2. Præopercular spine moderate, extending about $\frac{1}{2}$ the distance from its base to the vertical from the base of pectoral.

a. Third and fourth branched rays of the ventral fins longest, considerably longer than the first branched ray.

Diameter of eye 6 in the length of head, which is $3 \frac{1}{2}$ in the length of the fish (in specimens of 55 to $60 \mathrm{~mm}$.) ; origin of anal nearer to tip of snout than to base of caudal

microphthalmus, sp. n.

Diameter of eye 4 to 5 in the length of head, which is 4 in the length of the fish (in specimens of 40 to $75 \mathrm{~mm}$.) ; origin of anal equidistant from tip of snout and base of caudal, or nearer the former length of the fish (in specimens of 50 to $75 \mathrm{~mm}$.) ; origin of anal nearly equidistant from tip of snout and base of caudal . . . . . . . arafurensis, sp. n.

b. Branched rays of the ventral fins subequal, the third and fourth not or scarcely longer than the first.

Distance from tip of snout to extremity of maxillary 3 the length of head; least distance between eye and maxillary a little less than the diameter of eye. omanensis, sp. $n$.

Distance from tip of snout to extremity of maxillary $\frac{2}{3}$ the length of head; least distance between eye and maxillary considerably less than the diameter of eye .

capensis, sp. n.

B. Distance between origins of dorsals less than $\frac{1}{3}$ of the distance from tip of snout to origin of spinous dorsal . . . . . . . . . fimbriatus, Gilb., 1905.

\section{Champsodon guentheri, sp. n.}

Champsodon vorax (non Günth., 1867), Günth. 'Challenger' Shore Fishes, p. 52, pl. xxiii. fig. A (1880).

Depth of body $5 \frac{1}{2}$ in the length, length of head $3 \frac{1}{2}$ to $3 \frac{3}{5}$. Snout $1 \frac{1}{2}$ to $1 \frac{3}{4}$ as long as eye, the diameter of which is 5 to $5 \frac{1}{3}$ in the length of liead and greater than the interorbital wilth. Pramaxillaries without anterior notch; maxillary extending to below posterior edge of eye or a little beyond; distance from tip of snout to end of maxillary a little more than $\frac{1}{2}$ the length of head; least distance between eye and maxillary $\frac{2}{3}$ to $\frac{3}{4}$ the length of head, proopercular spine of moderate length; 11 or 12 gill-rakers on the lower part of the anterior arch. Dorsal V, I 19-20; second dorsal spine nearly $\frac{1}{3}$ the length of head; distance between origins of dorsals about $\frac{2}{5}$ of the distance from tip of snout to origin of spinous dorsal. Anal I 17-18; origin equidistant from tip of snout and base of caudal or nearer the latter. Ventrals $\frac{3}{4}$ to $\frac{5}{6}$ the length of head, extending to the origin of anal in the young, but not in the adult. Silvery; back darker; caudal dark at the base.

Philippine Islands, 115 fathoms; and Nares Harbour, Admiralty Islands.

Two specimens, 90 and $140 \mathrm{~mm}$. in total length, from the 'Challenger' collection. The smaller example, from the Admiralty Islands, has not been included in the description.

Champsodon capensis, sp. n. (Plate 27. fig. 2.)

Depth of body 5 in the length, length of head 4. Snout from as long to $1 \frac{2}{5}$ as long as eye, the diameter of which is 4 to $5 \mathrm{in}$ the length of head and greater than the inter- 
orbital width. Promaxillaries with a double notch anteriorly; maxillary extending beyond the vertical from posterior edge of eye; distance from tip of snout to end of maxillary $\frac{3}{5}$ the length of head; least distance between eye and maxillary $\frac{3}{5}$ the diameter of eye; præopercular spine of moderate length; 10 gill-rakers on the lower part of the anterior arch. Dorsal V, I 19; second spine $\frac{2}{5}$ the length of head; distance between origins of dorsals nearly $\frac{1}{2}$ the distance from tip of snout to origin of spinous dorsal. Anal I 17 ; origin equidistant from tip of snout and base of caudal or nearer the former. Pectoral $\frac{2}{5}$ the length of head; ventrals $\frac{4}{5}$ or $\frac{5}{6}$ the length of head, in the young reaching the origin of anal. A series of dark spots or vertical bars on the side; fins yellow, the caudal dark at the base.

South Coast of Cape Colony, 30 to 35 fathoms.

Four specimens, 40 to $75 \mathrm{~mm}$. in total length, collected and presented to the British Museurn by Dr. J. D. F. Gilchrist,

\section{Champsodon arafurensis, sp. n.}

Depth of body about 5 in the length, length of head $3 \frac{1}{3}$ to $3 \frac{1}{2}$. Snout $1 \frac{1}{4}$ to $1 \frac{1}{2}$ as long as eye, the diameter of which is $4 \frac{1}{2}$ to 5 in the length of head and greater than the interorbital width. Promaxillaries with a double notch anteriorly; maxillary extending beyond the vertical from posterior edge of eye; distance from tip of snout to end of maxillary ${ }_{5}^{3}$ the length of head; least distance between eye and maxillary less than the diameter of eye; præopercular spine of moderate length; 9 to 11 gill-rakers on the lower part of the anterior arch. Dorsal IV-V, I 18-19; second spine a little more than 3 the length of head; (listance hetween origins of dorsals about $\frac{2}{5}$ the distance from tip) of snout to origin of spinous dorsal. Anal I 17; origin nearly equidistant from tip of snout and base of caudal. Ventrals a little shorter than the head, extending to the origin of anal. Silvery; back darker; upper parts of spinous dorsal sometimes blackish.

Arafura Sea and Ki Islands, 129 fathoms.

Three specimens, 50 to $75 \mathrm{~mm}$. in total length, from the 'Challenger" collection.

This species seems to be nearest to the one figured by Alcock (Ill. Zool. 'Investigator,' pl. xxviii. fig. 5), and may be the same.

\section{Champsodon omanensis, sp. n. (Plate 27. fig. 1.)}

Depth of body about 5 in the length, length of head $3 \frac{1}{5}$ to $3 \frac{1}{2}$. Snout $1 \frac{1}{4}$ to $1 \frac{1}{2}$ as long as eye, the diameter of which is 5 to $5 \frac{1}{2}$ in the length of head and a little greater than the interorbital width. Promaxillaries with a double notch anteriorly; maxillary extending beyond the vertical from the posterior edge of eye; distance from tip of snout to extremity of mixillary 5 the length of head; least distauce between cye aud mixillary nearly equal to the diameter of eye; præopercular spine of moderate length; 9 or 10 gill-rakers on the lower part of anterior arch. Dorsal (IV) V, I 19 (20); second spine a little more than $\frac{1}{3}$ the length of head; distance between origins of dorsals $\frac{2}{5}$ or more than $\frac{2}{5}$ the distance from tip of snout to origin of first dorsal. Anal I 17; origin a little nearer to base of caudal than to tip of snout. Pectoral $\frac{2}{5}$ the length of head; ventral $\frac{2}{3}$ to $\frac{3}{4}$ the length of head, nearly reaching the origin of anal in the young. Silvery; 
back darker; fins yellowish or dusky; a dark spot on the basal part of the caudal continued into a dusky stripe on each lobe.

Sea of Oman, 140 to 200 fathoms.

Three specimens, 70 to $100 \mathrm{~mm}$. in total length, collected and presented to the British Museum by F. W. Townsend, Esq.

Champsodon vorax.

Champsodon vorax, Günth. Proc. Zool. Soc. 1867, p. 102.

Depth of body 5 in the length, length of head $3 \frac{3}{4}$. Snout scarccly longer than ere, the diameter of which is $4 \frac{1}{2}$ in the length of head and greater than the interorbital width. Priemaxillaries mith a clouble notch anteriorly; maxillary extending beyond the vertical from posterior edge of eye; distance from tip of, snout to end of maxillary $\frac{2}{3}$ the length of head; least distance between eye and maxillary considerably less than the diameter of eye. Dorsal V, I 19 ; distance between origins of dorsals about $\frac{2}{5}$ the distance from tip of snout to origin of spinous dorsal. Anal I 17; origin a little nearer to base of caudal than to tip of snout. Ventrals $\frac{4}{5}$ the length of head.

China Seas.

A single specimen, less than $60 \mathrm{~mm}$. in total length, in poor condition; type of the species.

\section{Parapercididæ.}

145. Parapercis punctulata, C. \& V.

Maldives, $\mathrm{Y}$. Male, 35 fathoms.

\section{Trichonotidæ.}

PSAMMICHTHYS, gen. nov.

Body elongate, compressed, scaleless. Head naked; eyes very small, superior, placed close together; anterior nostril tubular; mouth oblique; lower jaw pointed, strongly projecting; maxillary exposed; tecth conical, in narrow bands in the jaws; gillmembranes narrowly attached to the isthmus. A single dorsal fin with 19 rays, the first 5 of which are flexible spines; anal with 14 rays, the first spinous; caudal somewhat pointed; pectoral with 8 rays; ventrals close together, a little in advance of the pectorals, each with a spine and 5 soft rays, the inner rays the longest. 24 myotomes.

146. Psammichthys nudus, sp. 1. (Plate 31. fig. 1.)

Deptl of body 7 to $7 \frac{1}{2}$ in the length, length of head 4 to $4 \frac{1}{4}$. Snout short, maxillary extending to below the eye or a little beyond. Dorsal V 14, the fifth spine rather widely separated from the fourth and from the first articulated ray. Anal I 13. Pectoral shorter than ventrals, which are $\frac{1}{2}$ the length of head. Uniformly brownish.

Seychelles Group, Praslin Reef, from sand-siftings.

Three specimens, the largest $38 \mathrm{~mm}$. in total length.

147. Trichonotus setigerus, Bl. Schn.

Cargados Carajos, 20-30 fathoms. 


\section{Callionymidæ.}

148. Callionymus cooperi, sp. n.

Length of head (to gill-opening) $3 \frac{1}{2}$ in the length of the fish. Eyes subcontiguous, their diameter 3 in the length of head; gill-openings small, superior; præopercular spine with curved tip, with from 3 to 5 tooth-like projections on the upper edge and with an outer antrorse process at the base; maxillary not reaching the vertical from anterior edge of eye; occipital region rugose. Dorsal IV, 9; first 3 rays of anterior dorsal, in the male, produced into long filaments, of which the first, when laid back, reaches the caudal; second dorsal highest anteriorly, with the last ray longer than the 3 preceding it, but not reaching the caudal when laid back. Anal 8-9, the rays increasing in length posteriorly. Pectoral reaching to about the fourth anal ray, ventral to about the second. Caudal, in the male, of moderate length, less than $\frac{1}{2}$ as long as the fish. A series of dark spots along the middle of side; membrane of anterior dorsal dusky.

Maldives, Suvadiva and Haddumati, 40 to 44 fathoms.

'Two specimens ( $\mathrm{s} \mathrm{s}$ ), the larger $56 \mathrm{~mm}$. in total length.

Allied to C. sagitte, Pall.

149. Callionymus maldivensis, sp. n. (Plate 30. fig. 3.)

Length of head (to gill-opening) $3 \frac{1}{2}$ to 4 in the length of the fish. Diameter of eye 3 to $3 \frac{1}{2}$ in the length of head; eyes contiguous; gill-openings small, superior; præopercular spine straight, with serrated inner edge and an outer antrorse process at the base; maxillary extending nearly to the vertical from anterior margin of eye; occipital region rugose, not covered by skin. Lateral line single. Dorsal IV, 9; first ray of anterior dorsal, in the male, produced as a filament; second and third rays subequal, about $\frac{t}{5}$ the length of head ; rays of the second dorsal equal, the last reaching the caudal when laid back. Anal 8, the rays increasing in length posteriorly. Ventrals extending to the origin of anal, pectorals a little beyond. Caudal, in the male, elongate, as long as the fish. Head and upper part of body spotted and marbled; 5 or 6 indistinct dark cross-bars on the back; males with an oblong blackish blotch on the throat; spinous dorsal, in the male, with several oblique dark stripes or series of spots and with a small black spot at the tip of the third ray; spinous dorsal, in the female, with 3 or 4 irregular dark oblique stripes and with a large spot on the upper part of the membrane between the third and fourth rays; second dorsal with 3 or 4 series of oblong dark spots; caudal with dark cross-bars; outer half of anal blackish.

Maldives, S. Nilandu, 30 to 36 fathoms.

Several specimens (including only one male), measuring up to $160 \mathrm{~mm}$. in total length.

Closely allied to C. murgaretce, Rggn., from Muscat, which has a larger eye, the occiput covered with skin, and the coloration of the spinous dorsal different. 
150. Callionymus affinis, sp. n.

Length of head (to gill-opening) $3 \frac{4}{5}$ in the length of the fish. Diameter of eye $2 \frac{4}{5}$ in the length of head; eyes contiguous; gill-openings small, superior; præopereular spine straight, with serrated inner edge and an outer antrorse process at the base; maxillary extending nearly to the rertical from anterior margin of eye; occipital region rugose, not covered by skin. Lateral line single. Dorsal IV, 9 ; the anterior fin, in the male, elevated, but with the rays scarcely produced; rays of the second dorsal equal, the last reaching the caudal when laid back. Anal 8, the rays increasing in length posteriorly. Pectorals and ventrals extending beyond origin of anal. Caudal, in the male, elongate, $\frac{3}{4}$ as long as the fish. Body with dark spots or bars. Males with a heart-shaped blackish blotch on the throat and with stripes on the gill-membranes. Spinous dorsal dark, with undulating oblique white lines and with two small black spots at the upper margin belind the second and third rays respectively; second dorsal with 3 series of oblong spots; caudal crossed by dark bars or series of spots; outer half of anal blackish.

Maldives, S. Nilandu, 30 fathoms.

A single specimen, $85 \mathrm{~mm}$. in total length.

Closely allied to C.persicus, Regan, which has a shorter head ( $4 \frac{1}{2}$ in the length of the fish in specimens of this size), the spinous dorsal rather more elevated and with the rays more produced and the caudal fin longer (as long as the fish in specimens of $90 \mathrm{~mm}$.). The two species are very similar in coloration, but in $C$. persicus there is only one black spot at the edge of the anterior dorsal fin, beliind the second ray.

\section{Callionymus gardineri, sp. n. (Plate 30. fig. 5.)}

Closely allied to $C$. maldivensis. Length of head (to gill-opening) $3 \frac{5}{6}$ in the length of the fish. Diameter of eye $3 \frac{3}{5}$ in the length of head; maxillary not extending to below the eye. Dorsal IV, 9; first ray of anterior dorsal, in the male, produced into a filament; second and third rays equal in length, $\frac{2}{3}$ the length of head. Anal 8 . Caudal, in the male, elongate, slightly more than $\frac{2}{3}$ the length of the fish. Head and body marbled or variegated; a small dusky area on the throat; spinous dorsal with undulating oblique stripes with dark edges, which break up posteriorly into series of spots enclosed in dark rings; a blackish spot just behind the tip of the third ray; second dorsal and caudal with white (in spirit) spots and rermiculations; caudal also with some dark spots; anal with a dark edge.

Cargados Carajos, 20 to 30 fathoms.

A single specimen ( $\left.\sigma^{*}\right), 220 \mathrm{~mm}$. in total length.

152. Callionymus laianus, Gthr.

This species, hitherto known only from the type, a male specimen dredged by the 'Challenger' at a depth of 129 fathoms near' the Ki Islands, betreen Australia and New Guinea, is represented in the Gardiner collection by a female, dredged at a depth of over 123 fathoms on the Saya de Malha Bank. The first dorsal ray is not produced, but in other respects this example closely resembles the type. 
153. Callionymus spiniceps, sp.n. (Plate 30. fig. 4.)

Length of head (to gill-opening) $3 \frac{3}{4}$ in the length of the fish. Snout as long as eye, the diameter of which is 3 in the length of head; eyes subcontiguous; gill-openings small, superior; præopercular spine straight, more than ? the length of head, with both edges serrated and an outer antrorse process at the base; maxillary not extending to below the eye; præorbitals with sermated edges and with additional series of serre; præfrontals denticulated; supraorbital ridges serrated, ending posteriorly in 2 or 3 spines; occipital region rugose, with 2 pairs of spines. Lateral line single. Dorsal IV, 8; first ray of anterior dorsal, in the male, produced into a long filament; rays of the second dorsal equal, the last reaching the caudal when laid back. Anal 8, the rays increasing in length posteriorly. Pectoral reaching the fourth anal ray, ventral to the second. Caudal, in the male, elongate, $\frac{2}{3}$ as long as the fish. Head and upper part of body with small dark spots. A large black spot, on the upper part of the membrane between the third and fourth rays of the anterior dorsal; second dorsal with 3 or 4 series of oblong dark spots; caudal with dark cross-bars; outer half of anal blackish.

Amirante, Sezchelles Group, over 30 fathoms.

A single specimen, $154 \mathrm{~mm}$. in total length.

154. Synchiropus secheliensis, sp. n. (Plate 30. fig 1.)

Length of head (to gill-opening) $3 \frac{1}{2}$ in the length of the fish. Eyes separated by a distinct interspace, their diameter 3 in the length of head; gill-openings lateral, in front of the upper part of the base of pectoral; præopercular spine strongly curved upwards and inwards at the tip and with two tooth-like processes on its upper edge. Lateral line single. Dorsal IV, 8 ; anterior dorsal, in the male, elevated and with the rays produced, but rapidly decreasing in length from the first, which is much longer than the head, to the last, which scarcely reaches beyond the origin of the second dorsal when laid back. Anal 7. Ventrals extending nearly to the origin of anal, pectorals a little bejond. Caudal moderately elongate. Head and body with 6 lroad reddish cross. bars separated by irregular narrow whitish interspaces; lower parts with white spots or vermiculations. First two rays of anterior dorsal and the membrane between them reddish, rest of the fin dusky; second dorsal crossed by 3 or 4 ol)lique reddish bands and spotted or vermiculated with white; caudal with 2 reddish cross-bars; outer $\frac{1}{2}$ of anal blackish; pectorals pale, ventrals pink with dusky edges,

Seychelles Group, 37 fathoms.

Two specimens (o $\mathrm{s}), 55 \mathrm{~mm}$. in total length.

Allied to S. lineolatus, C. \& V., differing in coloration and in the form of the praopercular spine and of the anterior dorsal fin.

155. Synchiropus altivelis, sp.n. (Plate 30. fig. 2.)

Length of head (to gill-opening) $3 \frac{1}{2}$ in the length of the fish. Eyes separated by a distinct interspace, their diameter $3 \frac{1}{3}$ in the length of head; gill-openiugs lateral, in front of the upper part of the base of pectoral; præopercular spine strongly curved upwards and inwards at the tip and with two tooth-like processes on its upper edge. Lateral line

SECOND SERIES.-ZOOLOGI, VOL. XII. 
single. Dorsal IV, 8; anterior dorsal elevated, but with the rays scarcely produced. Anal 7. Ventrals extending to the first or second, pectorals to the third or fourth ray of anal. Caudal subtruncate, moderately elongate. Spinous dorsal with rounded or oval spots; soft dorsal and anal dark-coloured posteriorly; pectoral with a few spots near the margin; ventrals with linear vermiculations and dark lower edge; caudal with two narrow cross-bars.

Seychelles Group, 44 fathoms.

One specimen, $58 \mathrm{~mm}$. in total length.

Allied to S. lineolatus, C. \& V., differing especially in the form of the præopercular spine.

\section{Blenniidæ.}

156. Salarias quadricornis, C. \& V.

Maldives; Chagos Archipelago, Peros; Cargados Carajos.

157. Salarias sumatranus, Blkr.

Maldives; Chagos Archipelago, Salomon.

158. Salavias fasciatus, Bl.

Seychelles Group, Coetivy.

159. Salarias seba, C. \& V.

Seychelles Group, Coetivy.

\section{Brotulidæ.}

160. Diplacanthopoma raniceps, Alcock.

Saya de Malha Bank, 300 to 500 fathoms.

\section{Antennariidæ.}

161. Antennarius coccineus, Less. \& Garn.

Chagos Archipelago, Peros.

162. Antennaius nummifer, Cur.

Maldives, Haddumati, 35 fathoms.

\section{Lophïidæ.}

SLADENIA, geu. nov.

Head less depressed than in other Lophiid genera; tail deeper than broad. Lower jaw with two series of teeth. Nasal saes papilliform, as in the Tetrodont genus 
Sphcroides, not compressed nor constricted at the base and with the nostrils placed anteriorly and posteriorly. No free opercular flap. No trace of the third (occipital) ray of the anterior dorsal, which is so constantly present in other members of the family; last ray of second dorsal cleft to the base. Pectoral with very long pseudobrachium, as in Chirolophius, Rgn.

163. Sladenia gardineri, sp. n. (Plate 32.)

Head $\frac{1}{2}$ as long as the fish. Snout 3 times as long as the eye, the diameter of which is 11 in the length of head. Spines on the head and humeral spines all short, simple, obtuse; supraorbital ridges not denticulater, each terminating in a spine posteriorly. Anterior pair of enlarged teeth of inner præmaxillary series fixed; largest of 2 or 3 on each side of the romer depressible. Dorsal II, II, 9 ; first two rays of spinous dorsal slender, setiform, the second $\frac{2}{5}$ as long as the first, which is $\frac{1}{2}$ the length of head; posterior part of spinous dorsal represented by 2 nearly completely concealed rays. Anal 6 . Pectoral 18. Dark greyish, with pale vermiculations; outer $\frac{1}{3}$ of pectoral pale.

Chagos Archipelago, Salomon, about 4.50 fathoms.

A single specimen, $500 \mathrm{~mm}$. in total length.

\section{Malthidæ.}

161. Halieutea hancocki, sp.n. (Plate 31. fig. 6.)

Disc subcircular, its length a little less than its breadth and a little more than the length of the tail, without the caudal fin. Disc edged with filaments; lower surface finely granular; upper surface with spines, most of which are 3-rooted, the enlarged spines not so strong as in $H$. stellata. Diameter of eye $\frac{1}{7}$ the length of the disc and a little more than the width of the concave interorbital region. Rostral tentacle 3-lobed, the median lobe the smallest. Width of mouth (measured from the extremity of one maxillary to that of the other) $\frac{2}{5}$ the width of the disc. Dorsal with 5 rays, anal with 4 , pectoral with 13 or 14 . Caudal $\frac{1}{4}$ the length of the fish (without the caudal), a little longer than the pectoral, which is $1 \frac{1}{2}$ as long as the ventral. Greyish, with traces of darker reticulations on the upper surface; fins pale.

Saya de Malha Bank, over 123 fathoms.

A single specimen, $130 \mathrm{~mm}$. in total length.

This species is allied to $H$. stellato, Wall., and to $H$. nigra, Alc.

Named after Lieut. Hancock, R.N., First Lieutenant of H.MI.S. Sealark.

\section{Balistidæ.}

165. Balistes niger, Trungo Park.

Naldives, Haddumati, 40 fathoms.

166. Balistes aculeatus, $\mathrm{L}$.

Maldives; Chagos Archipelago, Peros and Salomon. 
167. Balistes viridescens, B1. Schn.

Maldives.

168. Monacanthus oculatus, Gthr.

Maldives, S. Nilandu, 30 fathoms.

169. DLonacanthus nematophorus, Gthr.

Maldives, Suvadiva, 43 fathoms, and Mulaku, 27 fathoms; Seychelles Group, Amirante, 30 fathoms; Cargados Carajos, 20 to 30 fathoms.

170. Monacanthus oblongus, Schleg.

Seychelles Group, Amixante, 30 fathoms; Cargados Carajos, 20 to 30 fathoms.

171. Monacanthus melanistius, sp.n. (Plate 31. fig. 4.)

Depth of body about $2 \frac{1}{2}$ in the length, length of head 3 . Snout produced, with concave upper profile; upper angle of gill-opening nearly in the vertical from posterior edge of eye. Scales papilliform. Dorsal spine 4-sided, with 4 series of barbs, inserted over the middle of eye, when depressed reaching the origin of the second dorsal fin, which has 33 or 34 rays, the middle of which are the longest, nearly $\frac{2}{5}$ as long as the spine. Anal 30-32. Caudal rounded. Ventral spine immovable. Body with small scattered round dark spots; membrane of spinous dorsal blackish; caudal with irregular dusky bars.

Plankton, surface, near Farquhar Atoll.

Three specimens, the largest $60 \mathrm{~mm}$. in total length.

Allied to the Australian $M$. peronii, Holland.

172. Monacanthus setifer, Benn.

Seychelles, 37 fathoms.

173. Pseudaluteres nasicornis, Schleg.

Maldives, Suvadiva, 37 fathoms; Seychelles Group, Amirante, 30 fathoms.

\section{Ostraciontidæ.}

171. Ostrucion cornutus, L.

Cargados Carajos, 20 to 30 fathoms.

175. Ostracion concatenatus, $\mathrm{Bl}$.

Seychelles Group, Amirante, 30 fathoms; Cargados Carajos, 20 to 30 fathoms.

176. Ostracion fornasini, Bianci.

Seychelles Group, Amirante, 30 fathoms; Cargados Carijos, 20 to 30 fathoms. 


\section{Tetrodontidæ.}

177. Spheroides hypselogenion, Blkr.

Cargados Carajos, 20 to 30 fathoms.

178. Spheroides spinosissimus, sp.n. (Plate 31. fig. 5.)

Nostrils borne on a well-developed papilla. No distinct lateral fold. Length of head $2 \frac{2}{3}$ in the length of the fish. Snout short and broad, scrrcely longer than the eye, the diameter of which is $3 \frac{1}{3}$ in the length of head. Width of the slightly concave interorbital region $4 \frac{1}{3}$ in the length of head, much less than the interocular width. Head and body, except the tail, entirely covered with rather strong two-rooted spines. Dorsal 8, pointed, the anterior rays longest, $\frac{1}{2}$ the length of head. Anal 7. Caudal truncate. Brownish above, pale below ; a blackish spot above and behind the eye; a smaller blackish spot at the base of the dorsal; a diffuse dusky blotch on the side; fins pale, the caudal with a dark posterior edge.

Saya de Malha Bank, over 123 fathoms.

A single specimen, $90 \mathrm{~mm}$. in total length.

This fish bears a considerable resemblance to those of the genus Diodon.

179. Tetrodon stellatus, Bl. Schn.

Cargados Carajos, 20 to 30 fathoms.

180. Tetrodon meleagris, Lacep.

Chagos Archipelago, Peros.

181. Tetrodon nigropunctatus, B1. Schn.

Seychelles Group, Coetivy.

182. Tropidichthys valentini, Blkr.

Maldives, Haddumati, 40 fathoms; Seychelles, 37 fathoms.

183. Tropidichthys caudofasciatus, Gthr.

Seychelles Group, Amirante, 30 fathoms, and Seychelles, 37 fathoms.

184. Tropidichthys natalensis, Gthr.

Seychelles Group, Coetivy.

185. Tropidichthys bennetti, Blkr.

Maldives. 


\section{APPENDIX.}

The following is a list of Brackish-water Fishes, originally placed with the fresh-water forms from the Seychelles, \&c. :-

Chanos salmoneus, $\mathrm{Bl}$.

Haplochilus playfairi, Gthr.

Hemirhamphis far, Forsk.

MTugil oligolepis, Blkr.

Therapon jarbua, Forsk.

Ambassis urotania, Blkr.

Gerres lineolatus, Gthr.

Psettus argenteus, $\mathrm{L}$.

Trachynotus ovatus, $\mathrm{L}$.

Eleotris ophiocephalus, C. \& V.

Cryptocentrus octofasciatus, Rgn.

Periophthalmus koelreuteri, Pall.

Periophthalmus schlosseri, Pall.

Salarias oortii, Blkr.
Mangrove-swamp, Praslin, and lagoon, Silhouette, Seychelles. Mangrove-swamp, Praslin.

Mangrove-swamp, Praslin.

Mangrove-swamp, Praslin.

Mangrove-swamp, Praslin.

Mangrove-swamp, Mahé.

Lagoon, Silhouette, Seychellos.

Mangrove-swamp, Praslin, and lagoon, Silhouette.

Mangrove-swamp, Praslin.

Mangrove-swamp, Praslin.

Mangrove-swamp, Praslin.

Mangrove-swamp, Praslin, and lagoon, Silhouette.

Mangrove-swamp, Praslin.

Mangrove-swamp, Praslin.

\section{EXPLANATION OF THE PLATES.}

\section{Plate 23.}

Fig. 1. Borostomias braueri, sp. $\mathbf{n}$.

Fig. 2. Macrurus microstomus, sp. $\mathrm{n}$.

Fig. 3. Neocyttus acanthorhynchus, sp. n.

\section{Plate 24.}

Fig. 1. Apogon punctatus, sp. u.

Fig. 2. Amphiprion nigripes, sp. n.

Fig. 3. Pomacentrus polylepis, $\mathrm{sp} . \mathbf{n}$.

Fig. 4. Anthias cuoperi, Regan,

Fig. 5. Dascyllus nigripinnis, sp. $\mathbf{n}$.

Fig. 6. Hulacanthus somervillii, sp. n.

\section{Prate 25.}

Fig. 1. Sccoops maldivensis, $\delta$ and $q, \mathrm{sp} . \mathrm{n}$.

Fig. 2. ", filimanus, $\delta$ and $q$, sp. n.

Iig. 3. " latifrons, $\delta$ and $q, \mathrm{sp} . \mathrm{n}$. 


\section{Plate 26.}

Fig. 1. Cynoglossus sealarki, sp. n.

Fig. 2. Arnoglossus malhensis, sp. n.

Fig. 3. Platophrys circularis, sp. n.

\section{Plate 27.}

Fig. 1. Champsodon omanensis, sp. n.

Fig. 2. $\quad$ " capensis, sp. $\mathbf{n}$.

Fig. 3. Apogon maculipinnis, sp. n.

Fig. 4. Scceops macrolepis, sp. n.

Fig. 5. ", sechellensis, sp. n.

Fig. 6. Platophrys ovalis, sp. n.

\section{Plate 28.}

Fig. 1. Xenanthias gardineri, sp, n.

Hig. 2. Minous longimanus, sp. n.

Fig. 3. Pogonoscorpius sechellensis, sp. n.

Fig. 4. Lepidotrigla alcocki, sp. $\mathbf{n}$.

Fig. 5. Hoplichthys acanthopleurus, sp. n.

\section{Plate 29.}

Fig. 1. Gobiopterus modestus, sp. n.

Fig. 2. Cryptocentrus octofasciatus, sp. n.

Fig. 3. Hoplopomus acanthistius, sp. n.

Fig. 4. Platycephalus oligolepis, sp. n.

Fig. 5. $\quad$ cooperi, sp. n.

\section{Plate 30.}

Fig. 1. Synchiropus sechellensis, sp. $\mathbf{n}$.

Fig. 2. , altivelis, sp. $\mathbf{n}$.

Fig. 3. Callionymus maldivensis, sp. n.

Fig. 4. " spiniceps, sp. n.

Fig. 5. " gardineri, sp. n.

\section{Plate 31.}

Fig. 1. Psammichthys nudus, sp. n. (×2.)

Fig. 2. Champsodon sechellensis, sp. n.

Fig. 3. " microphthalmus, sp. n.

Fig. 4. Monacanthus melanistius, sp. n.

Fig. 5. Spheroides spinosissimus, sp. $\mathrm{n}$.

Fig. 6. Halieutea hancocki, sp. n.

\section{Plate 32.}

Sladenia gardineri, gen. et sp. nov. ( $\left(\times \frac{1}{2}\right.$. $)$ 


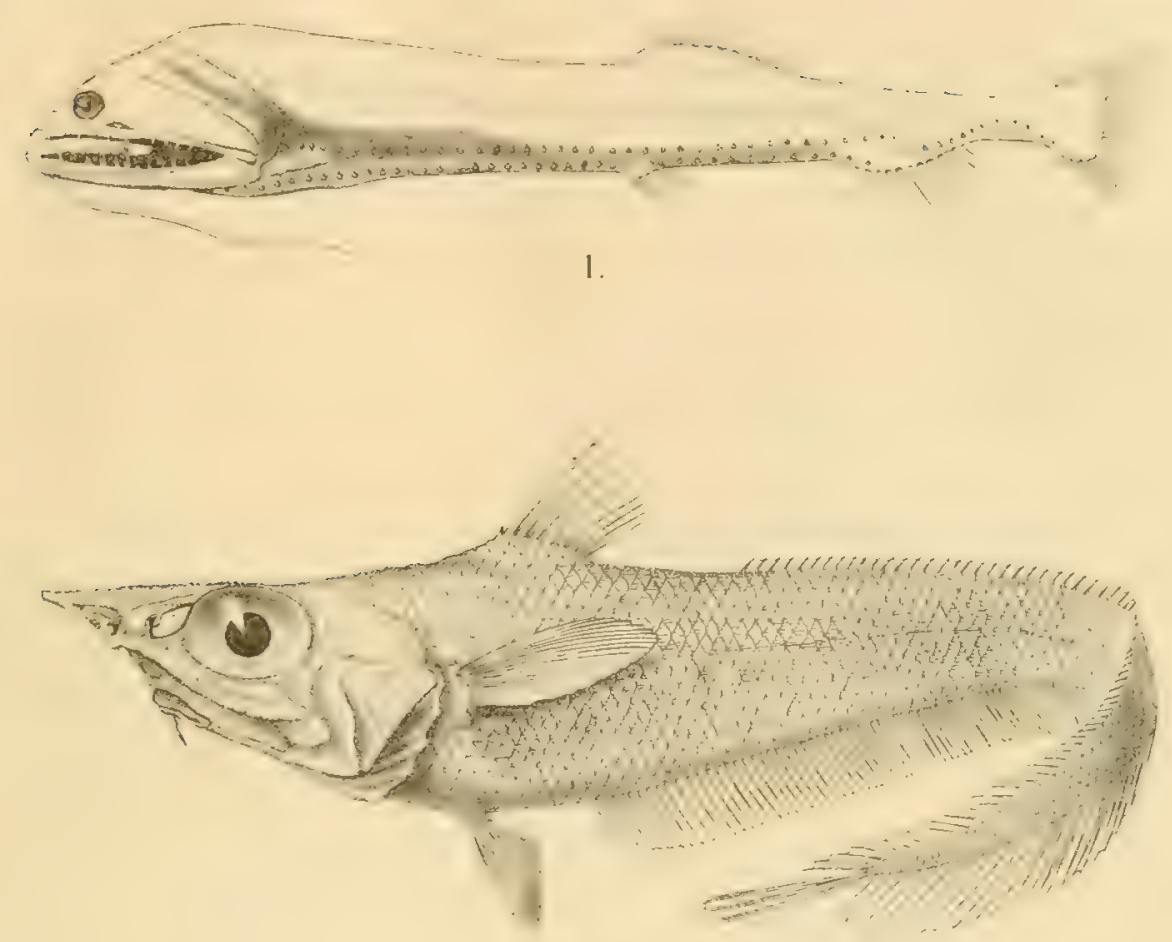

2.

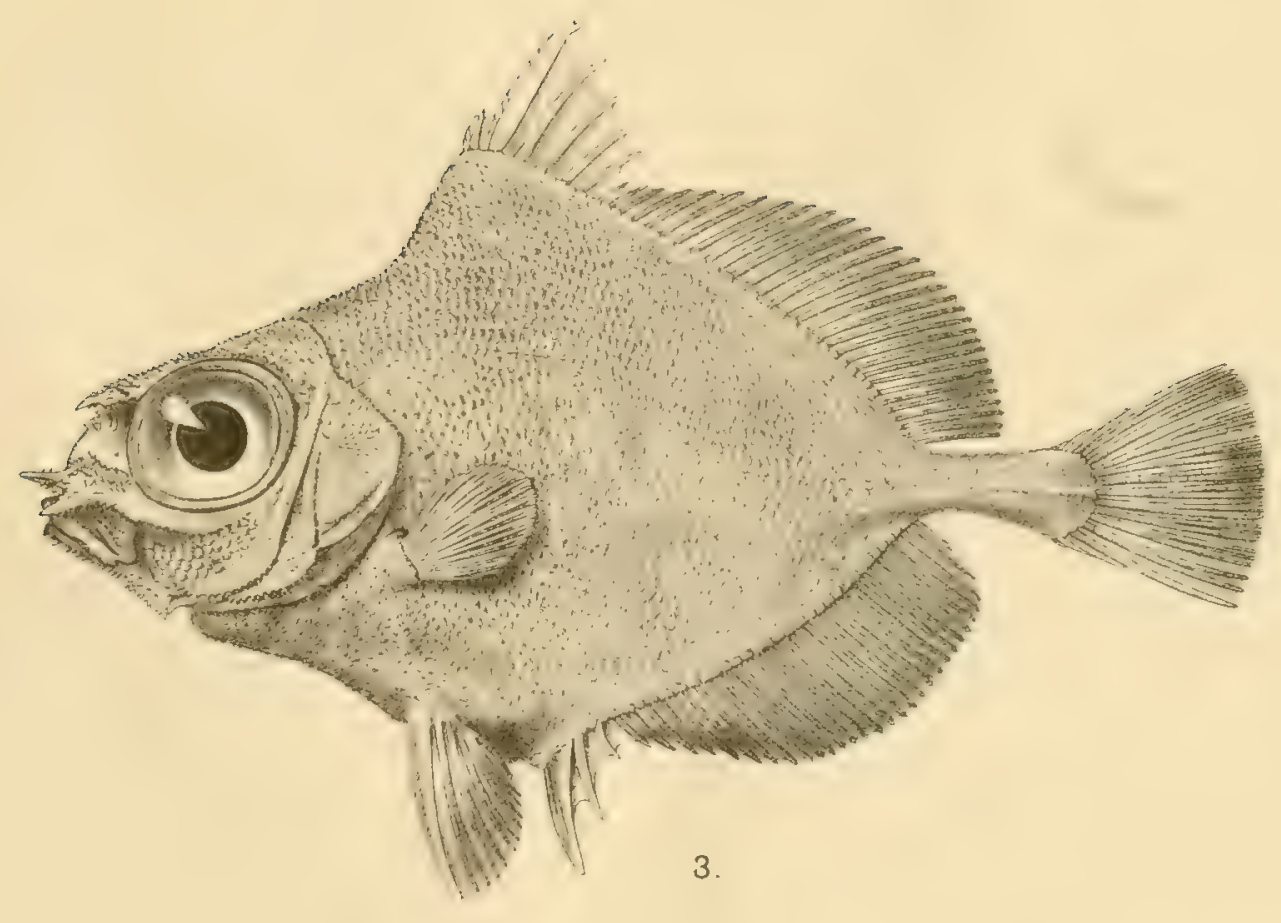



(REGAN)
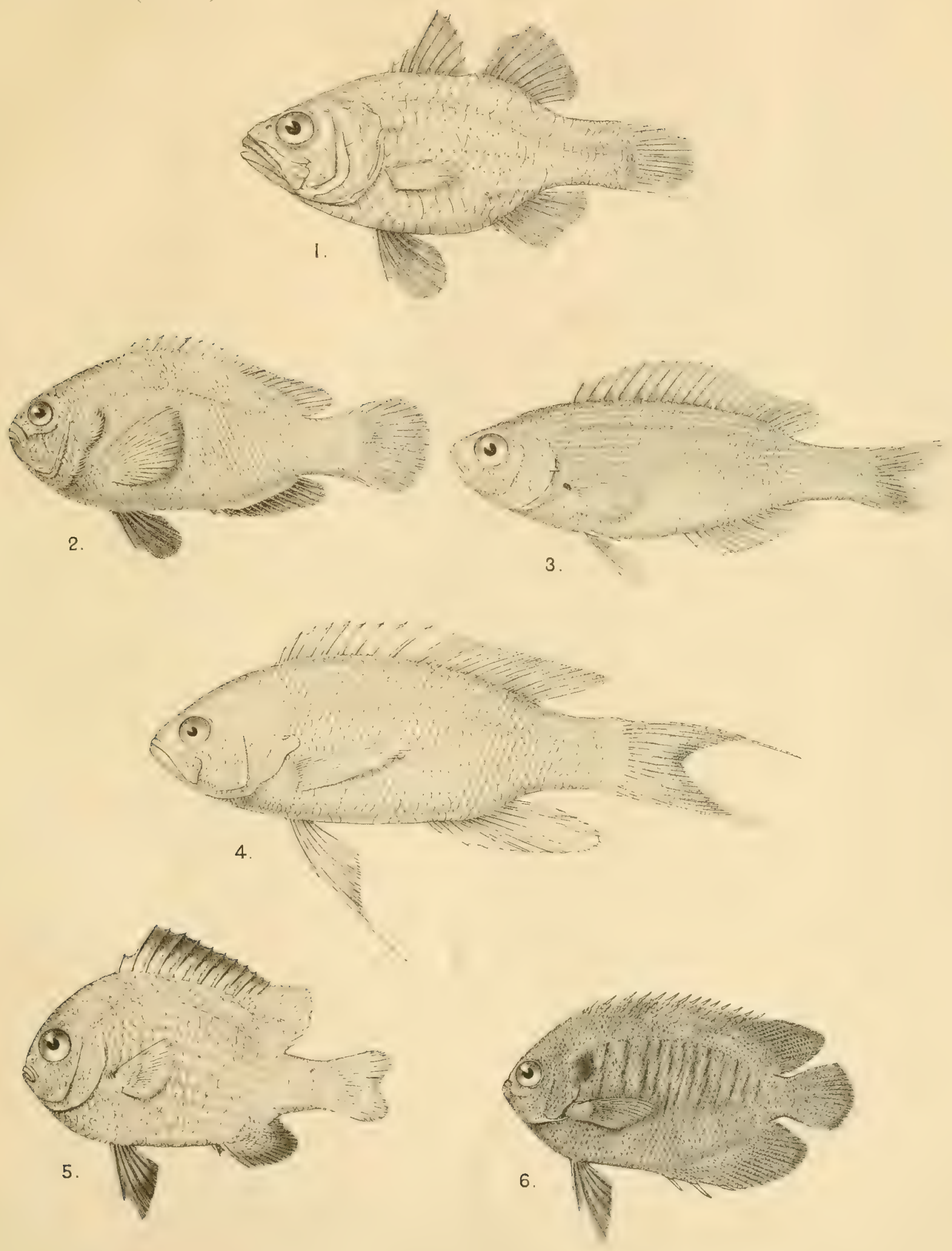

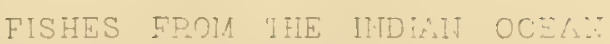




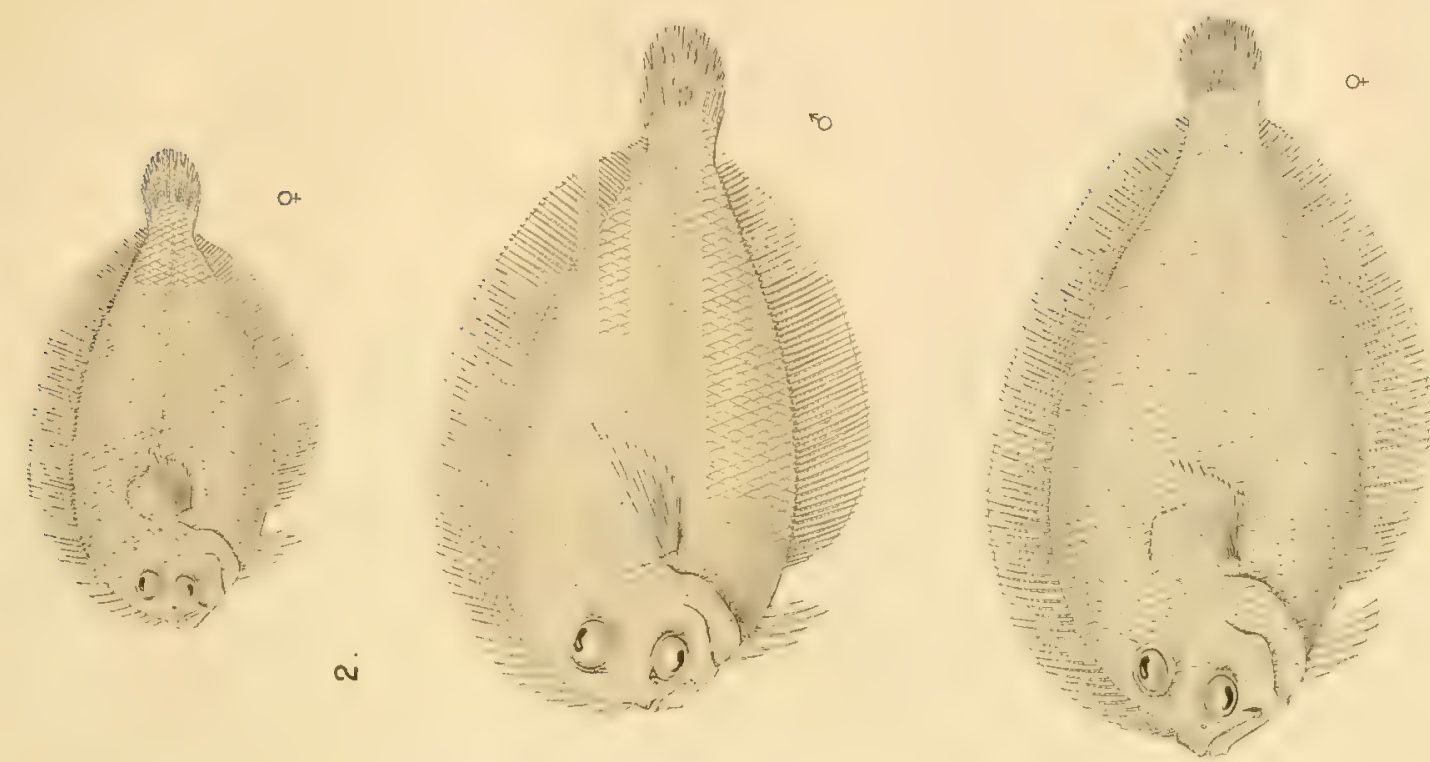

๓่

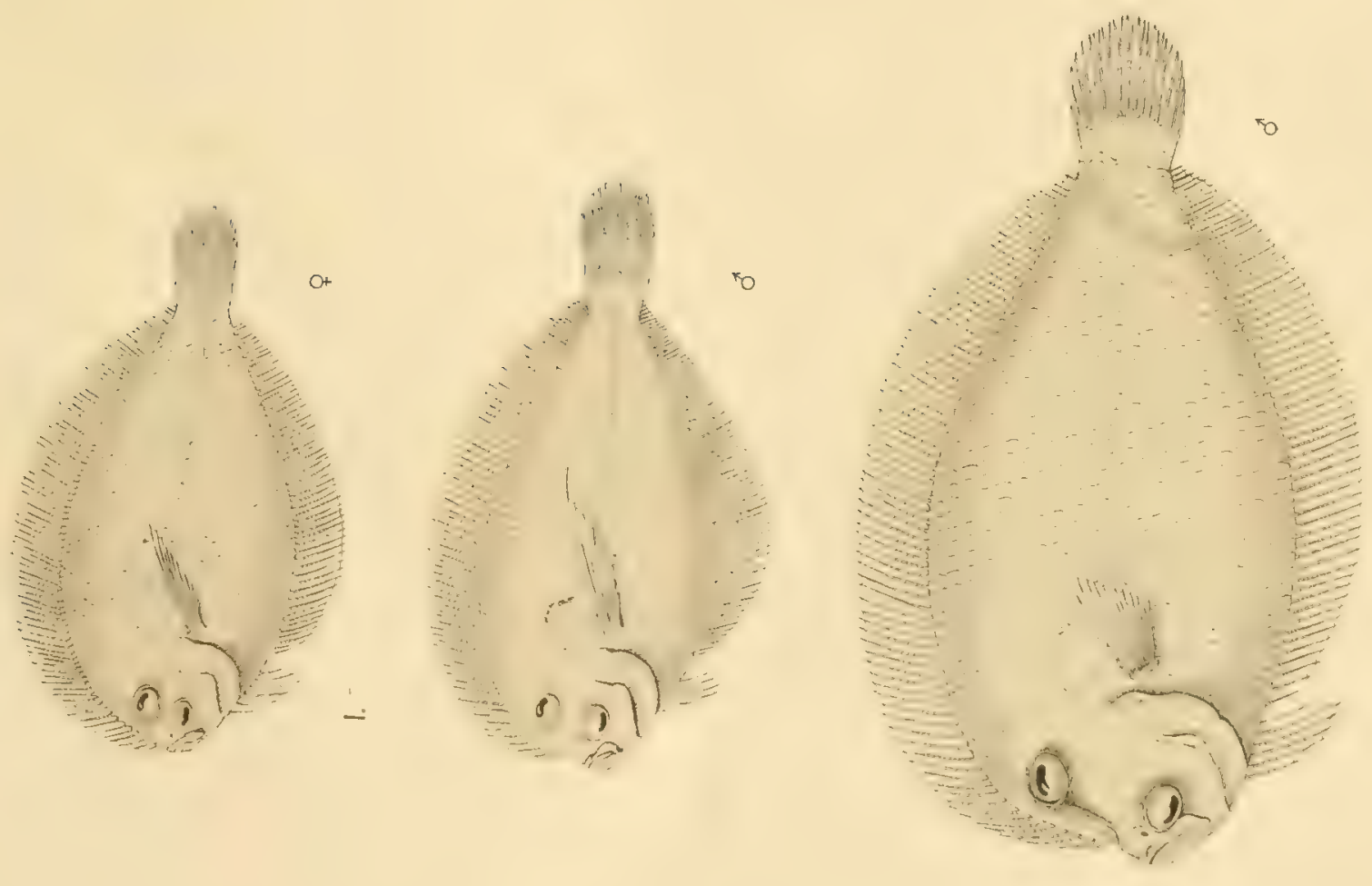

FISHES FROM THE INDIAN OCEAN. 



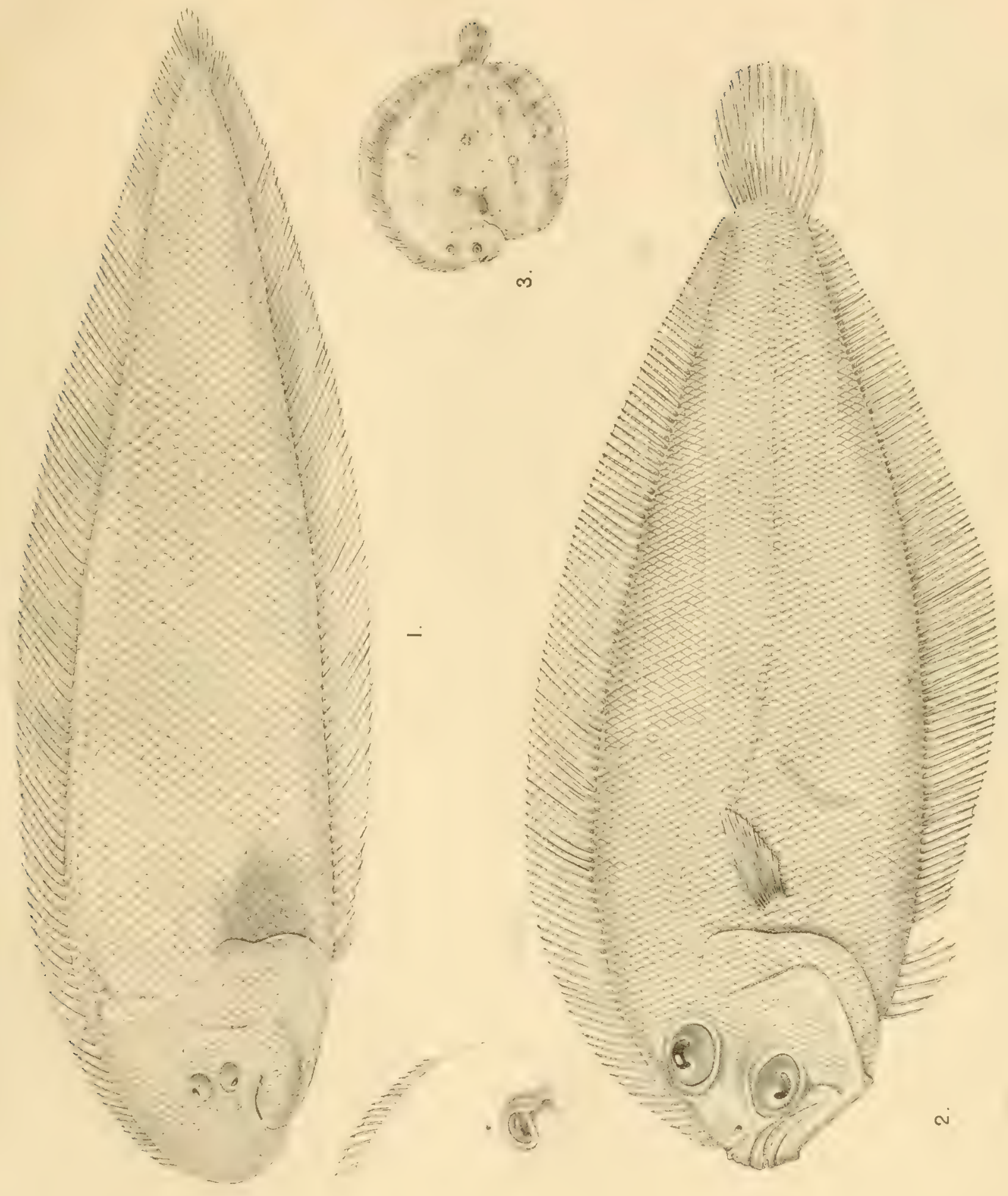




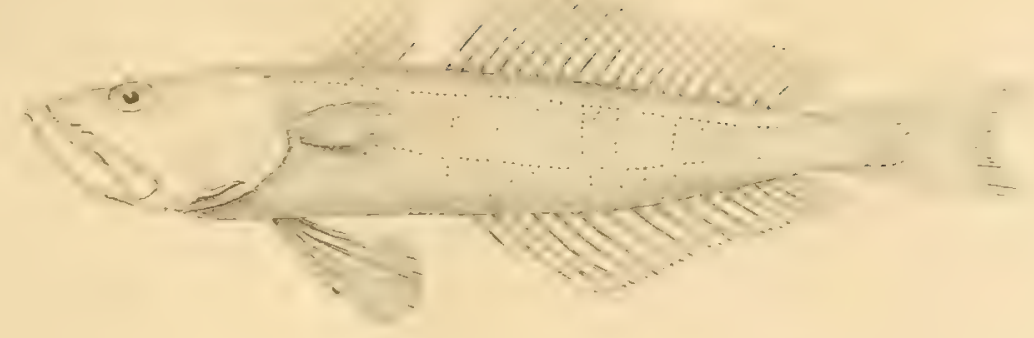

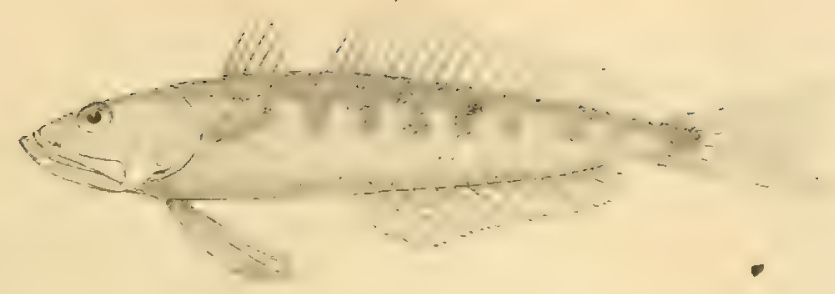

2.

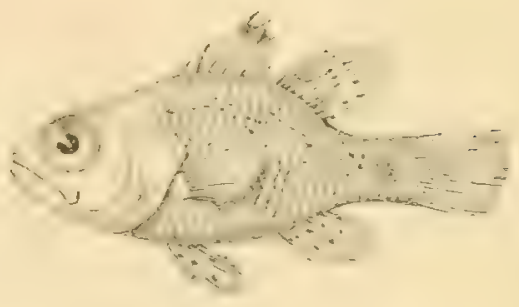

3.

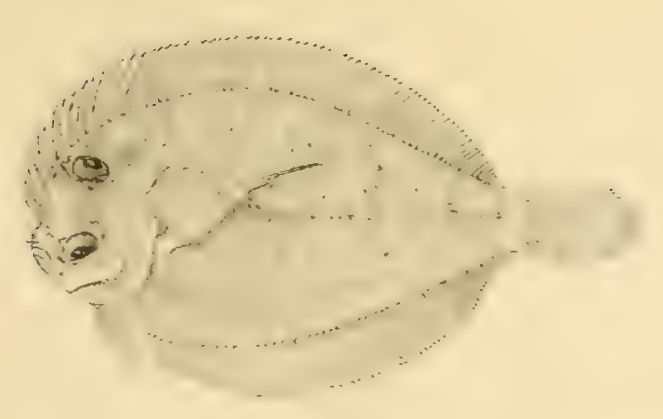

4.

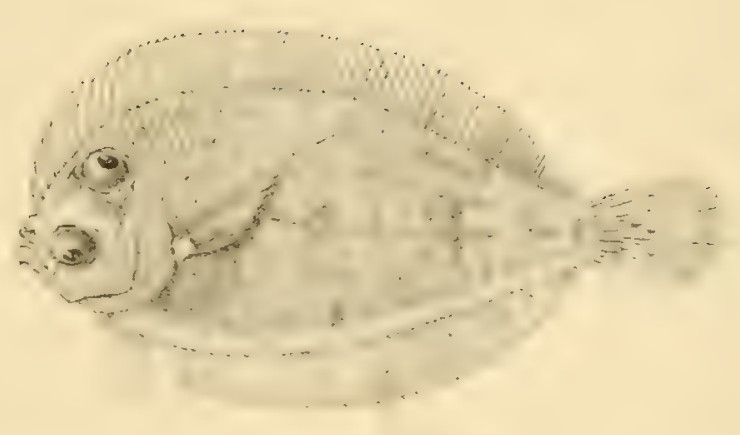

5.

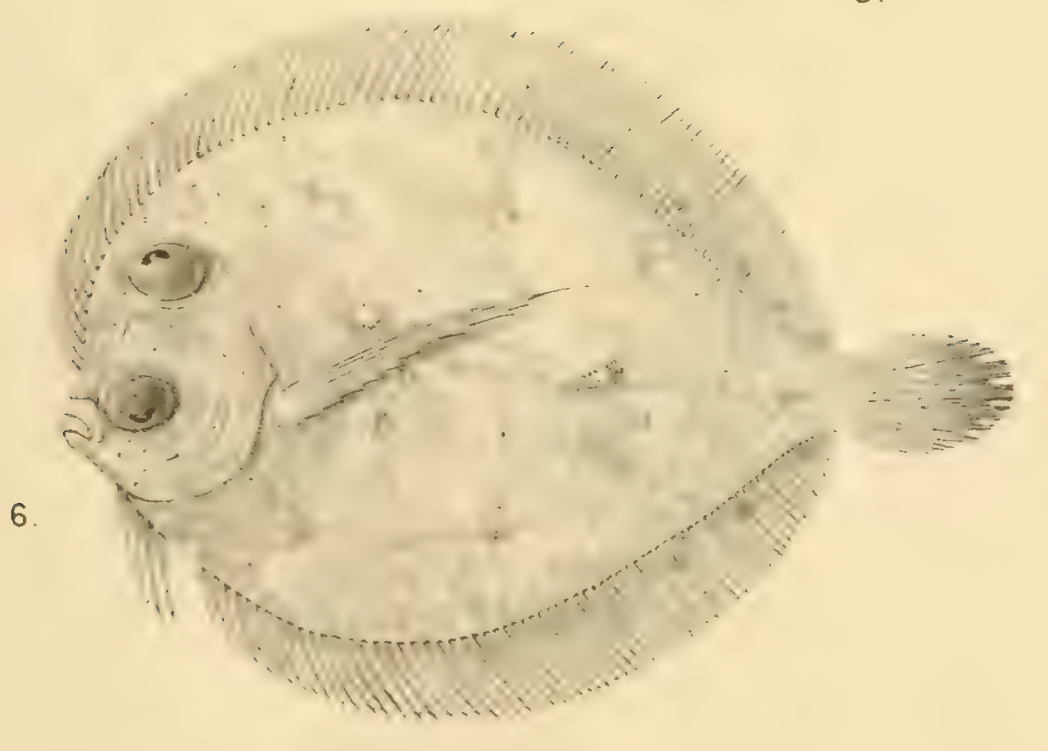

FISHES FROM THE INDIAN OCEAN. 



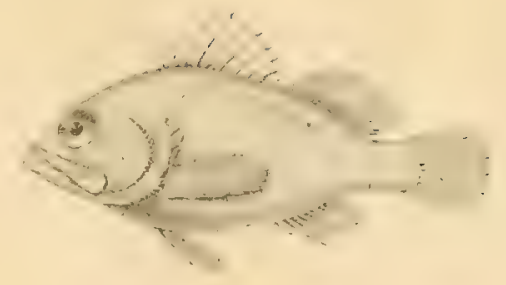

1.

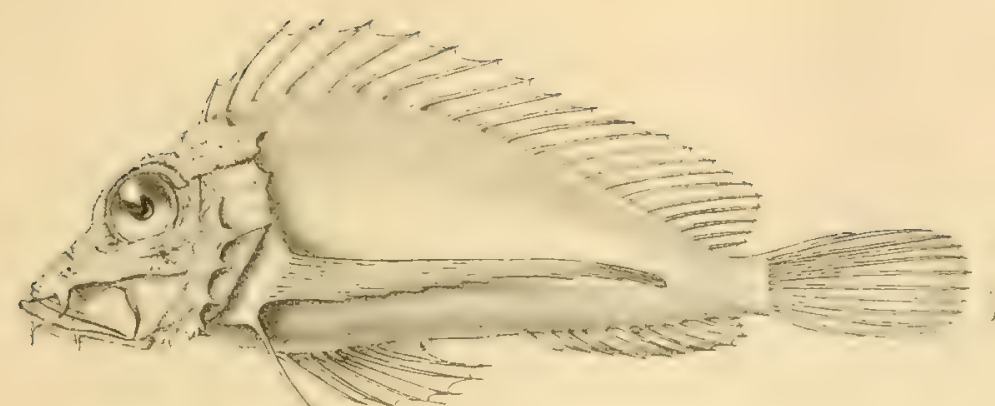

2.

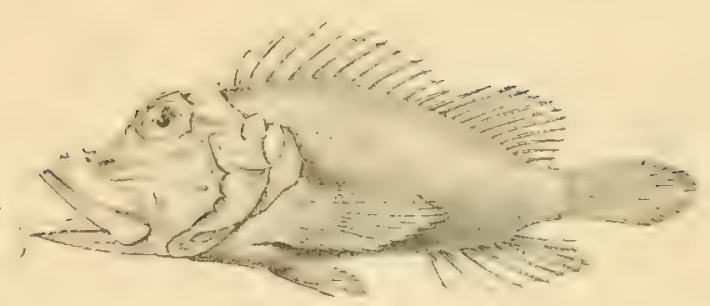

3.

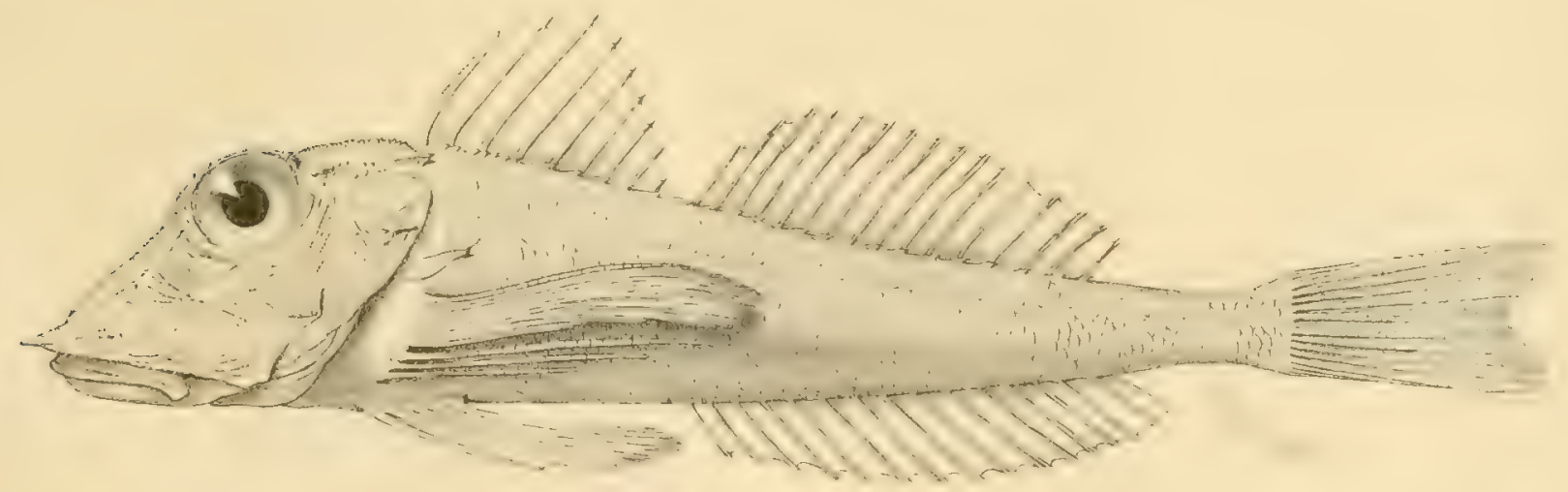

4.

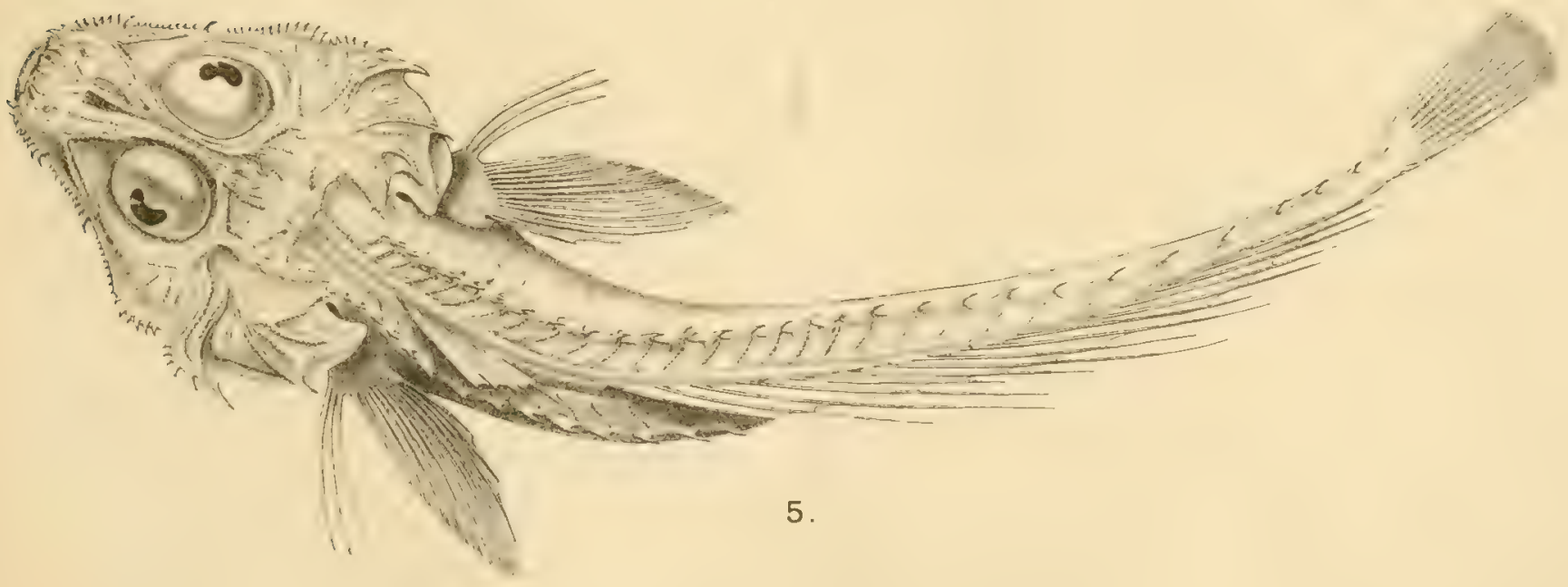



(REGAN)

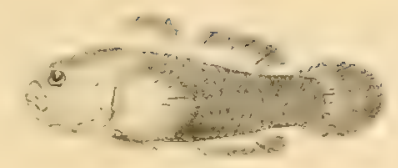

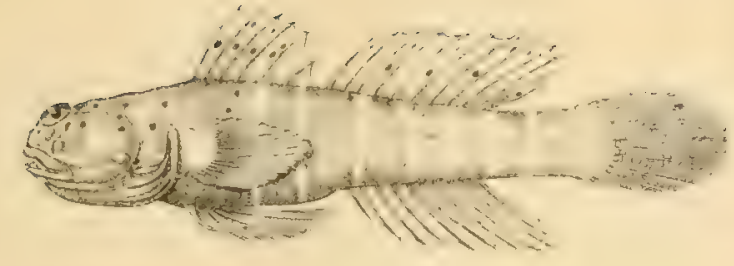

2.



3.

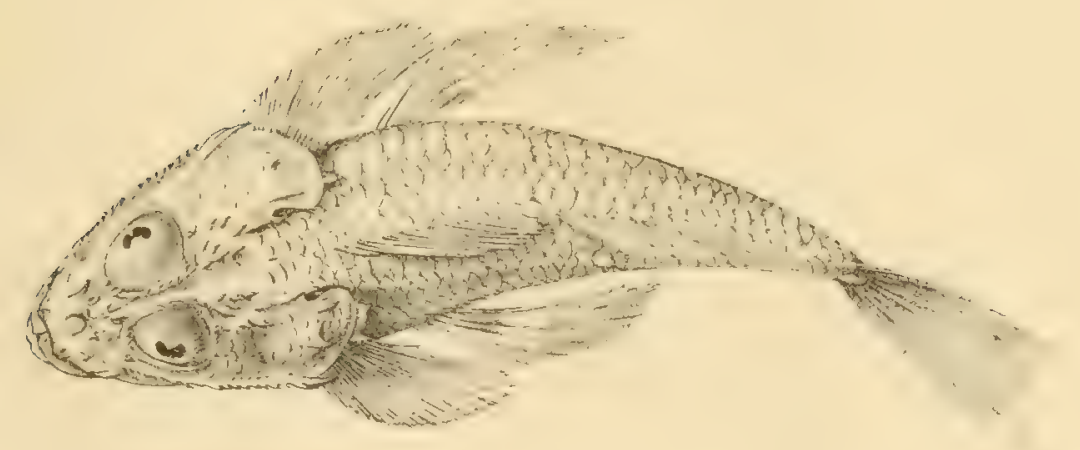

4.

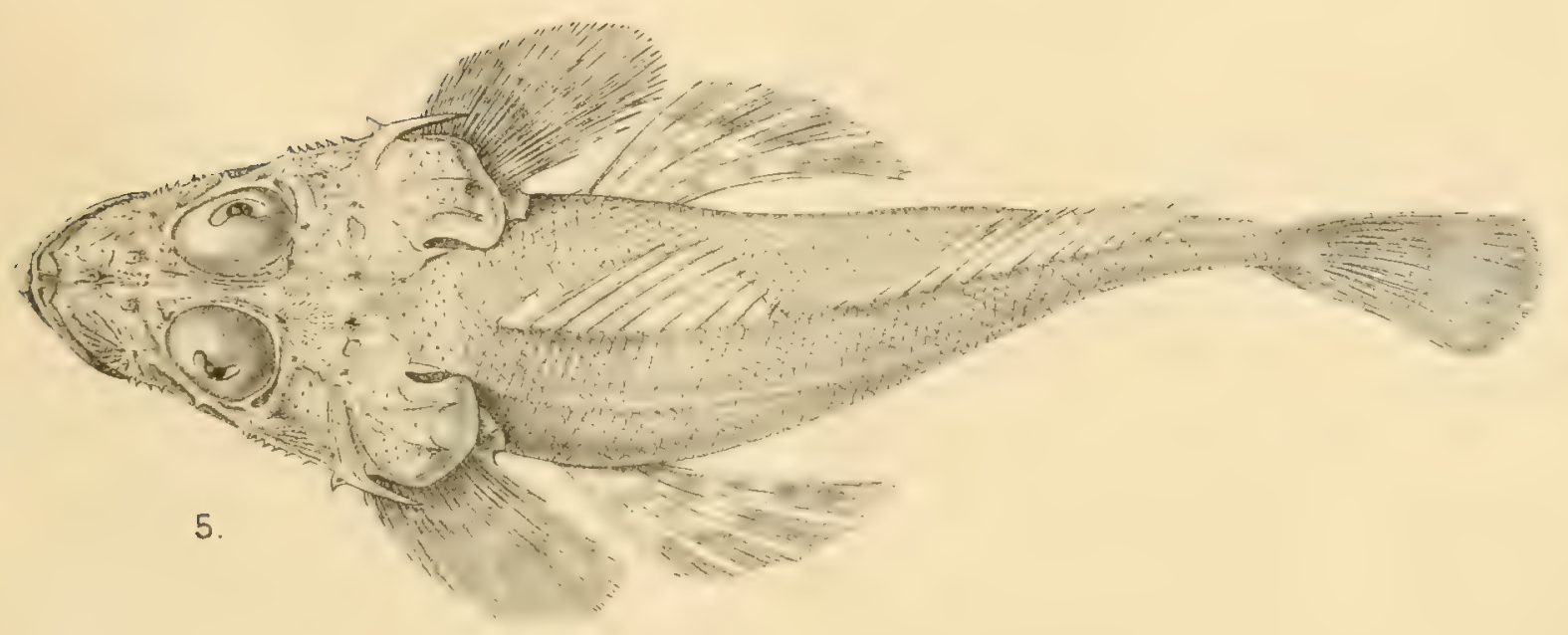




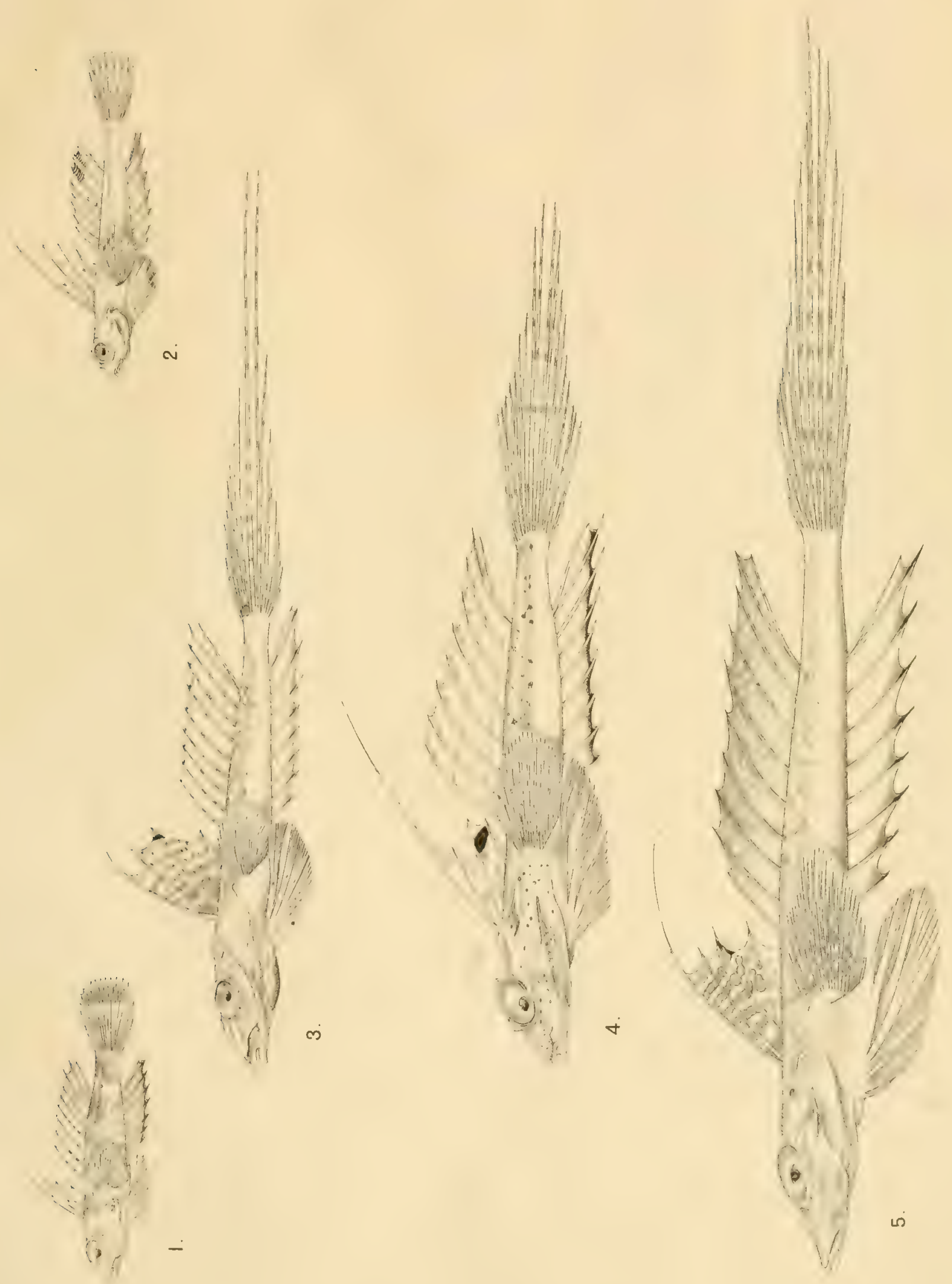


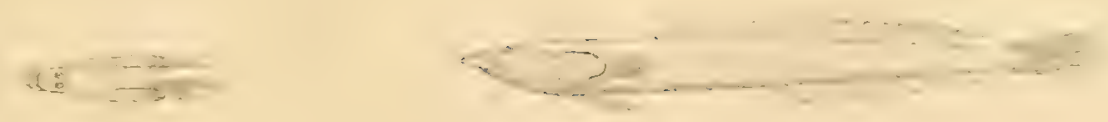

1.

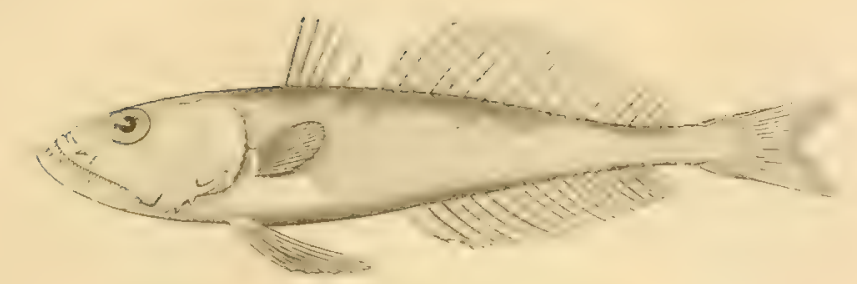

2.

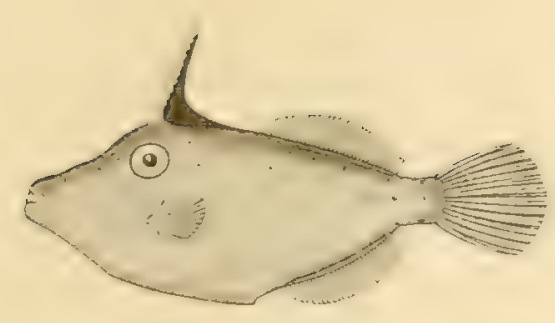

4.

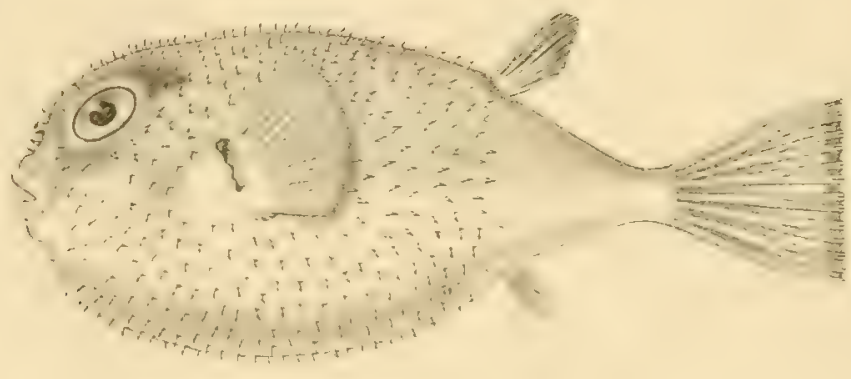

5

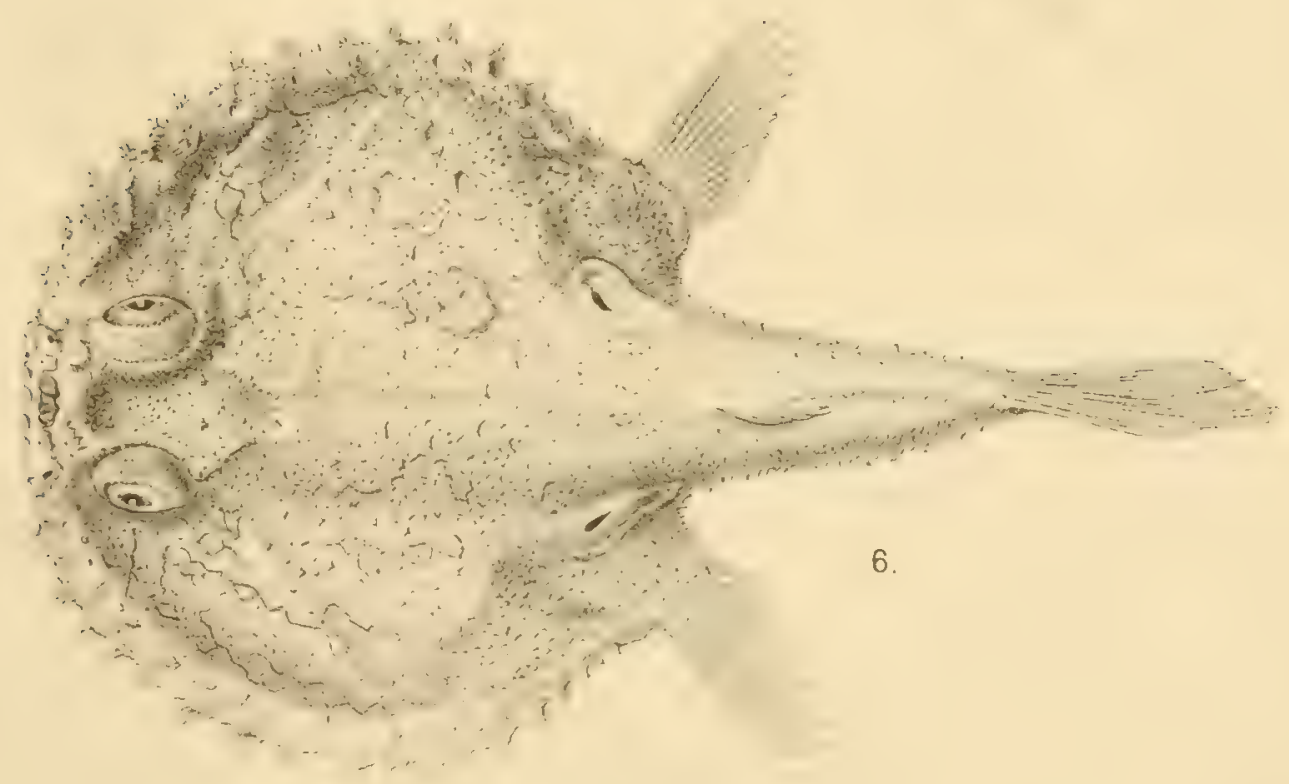





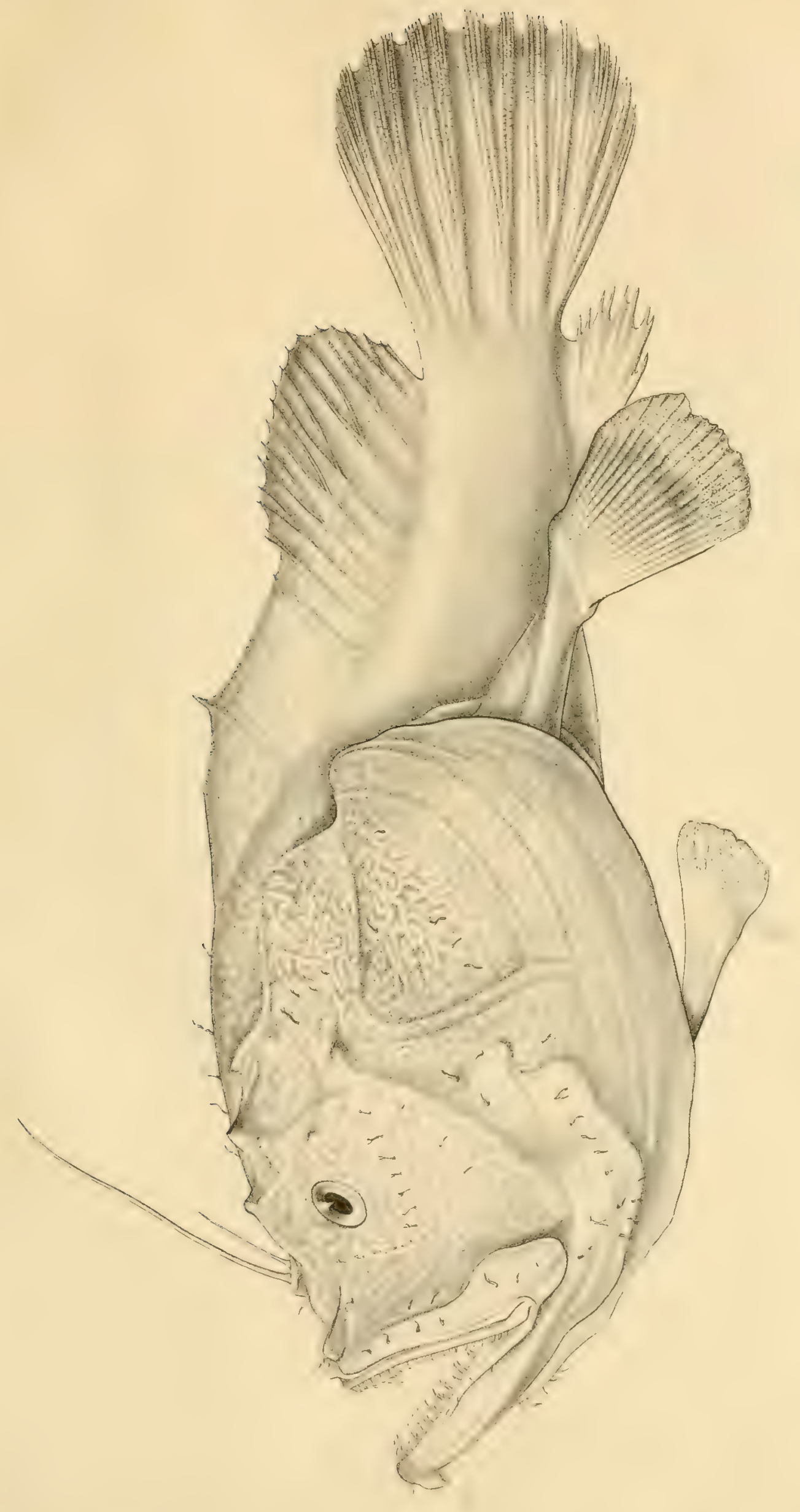





\section{MEMORANDA CONCERNING TRANSACTIONS.}

The First Series of the Transactions, containing both Botanical and Zoological contributions, has been completed in 30 Vols., and a few entire sets are still for sale. Only certain single rolumes, or parts to completo sets, may be obtained at the original prices. The price of the Index to Vols, $1-25$ is $8 s$. to the public, and 6 s. to Fellows; to Vols. 26-30, 4s. to the public, and $3 s$. to Fellows.

The Second Series of the Transactions is divided into Zoological and Botanical sections. The prices of the Zoological parts of those which have been published are as undermentioned:-

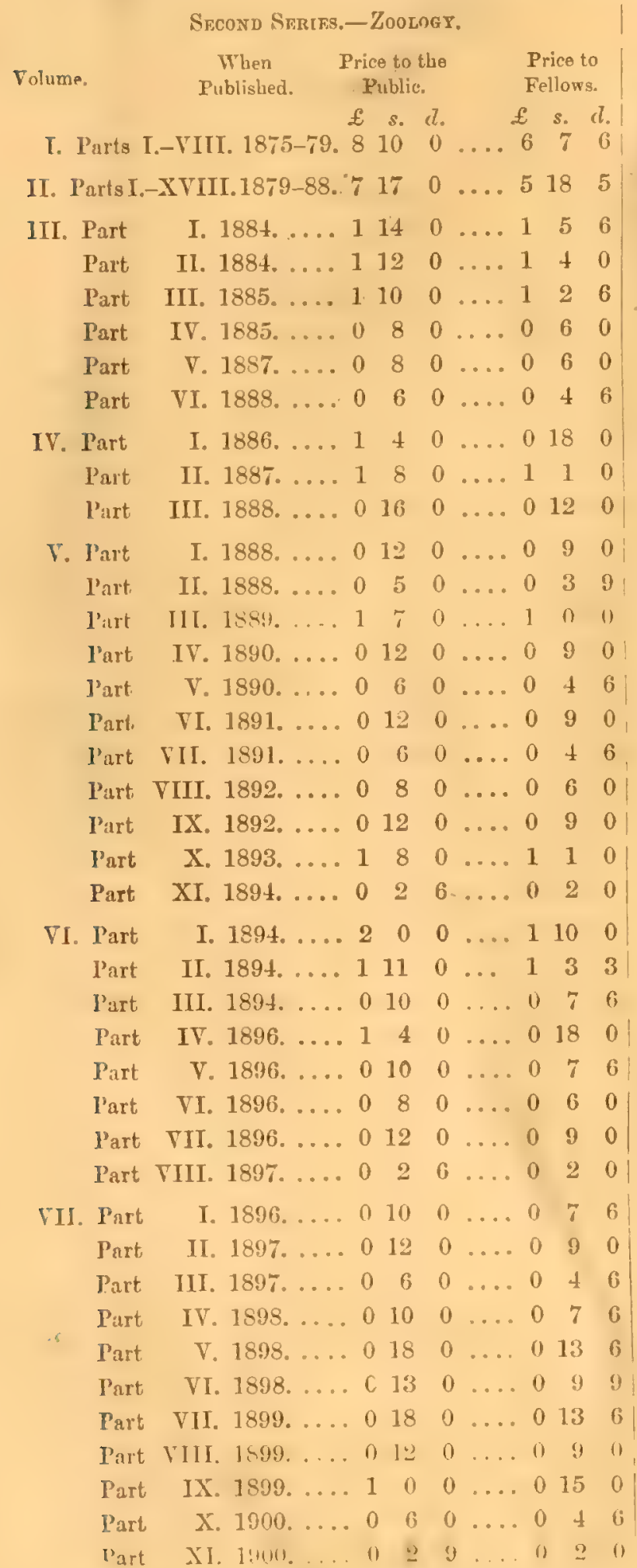

Second Sremes,-Zoology (continued).

Volume. When Price to the Price to

Published. Public. Fellows.

$£$ s. $d . \quad$ \& $s . d$

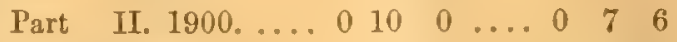

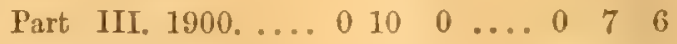

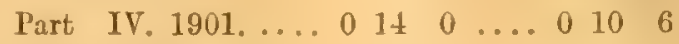

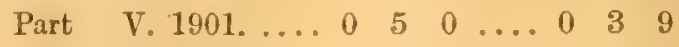

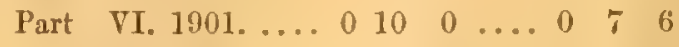

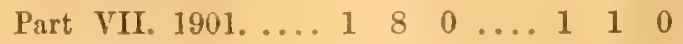

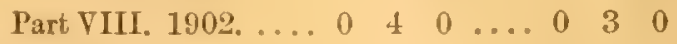

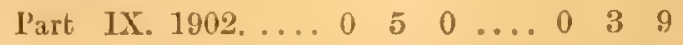

lart X. 1903.... $1000 \ldots 000$

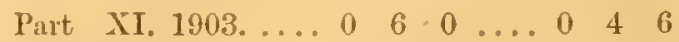



Part XIII. Index. $\ldots \begin{array}{lllllll}0 & 2 & 9 & \ldots & 0 & 2 & 3\end{array}$

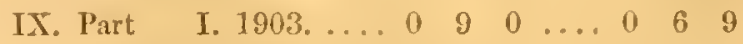



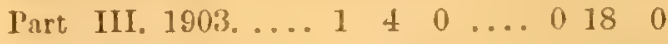

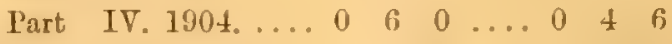

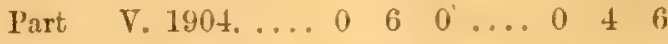

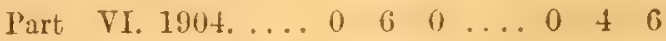

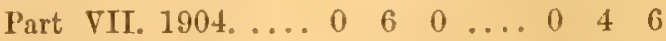

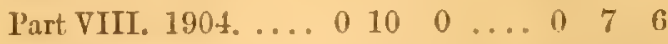

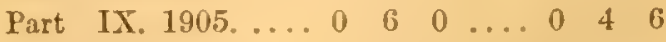

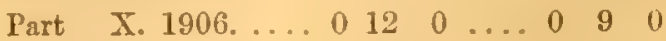

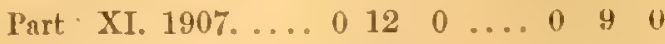

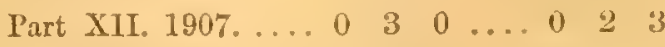

PartXIII. 190\%. . . 0 (i 0 ... ( ) 4 i



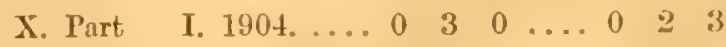

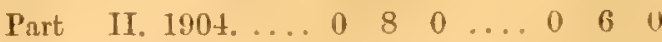

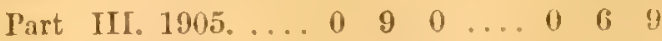

Part IV. $1905 . \ldots .01010 \quad 0 \quad \ldots .007$

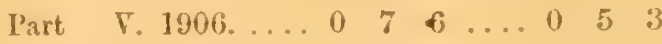

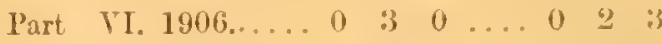

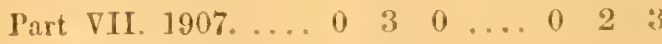


(In Progress.)

XI. Part I. (In Preparation.

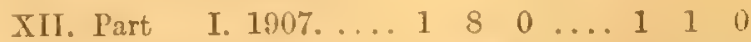

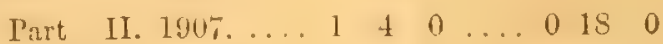

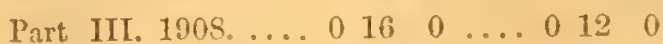





